
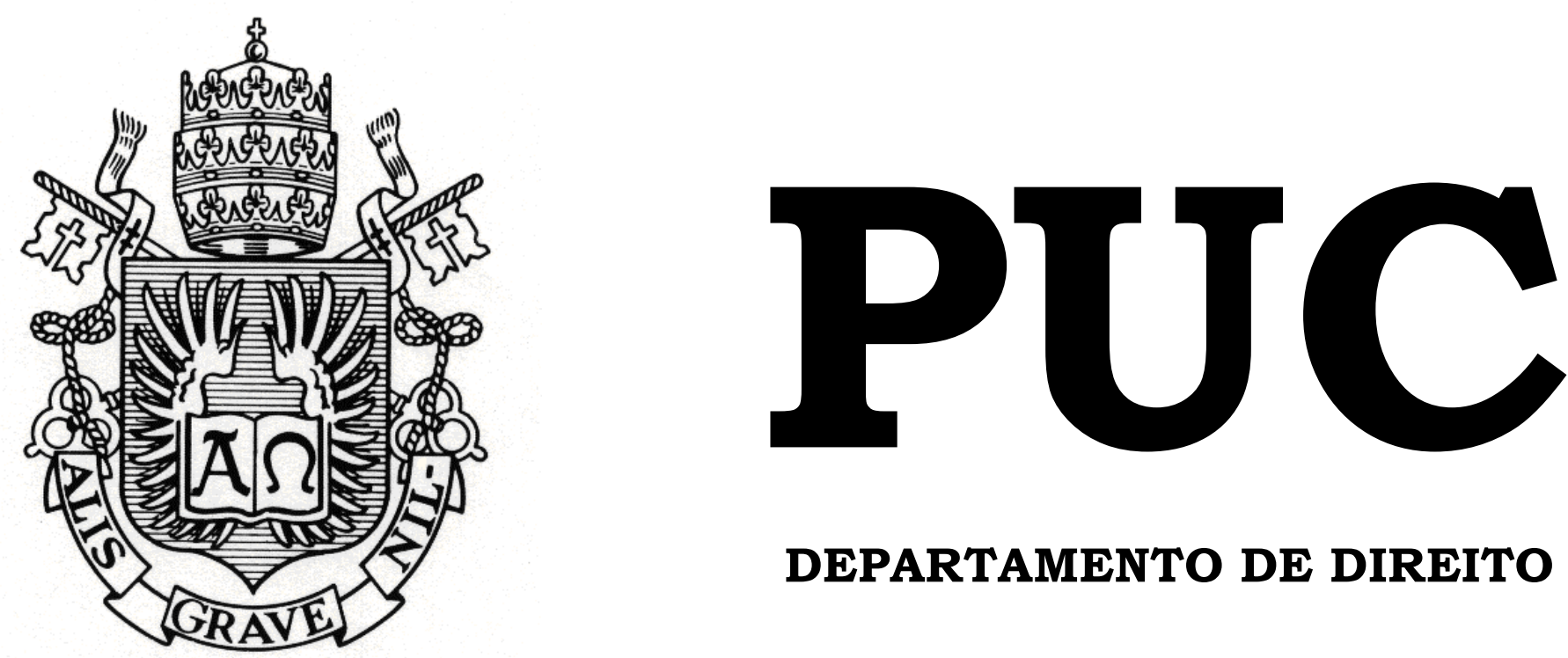

DEPARTAMENTO DE DIREITO

\title{
Remuneração dos Administradores de Companhias Abertas
}

por

Alexandre Infante de Castro

ORIENTADOR: Pablo Waldemar Renteria

2010.2

PONTIFÍCIA UNIVERSIDADE CATÓLICA DO RIO DE JANEIRO

RUA MARQUÊS DE SÃO VICENTE, 225 - CEP 22453-900

RIO DE JANEIRO - BRASIL 


\section{Remuneração dos Administradores de Companhias Abertas}

por

\section{Alexandre Infante de Castro}

Monografia

apresentada

ao

Departamento de Direito da Pontifícia Universidade Católica do Rio de Janeiro (PUC-Rio) para a obtenção do Título de Bacharel em Direito.

Orientador: Pablo Waldemar Renteria 
Aos meus pais, por todo carinho e dedicação; Aos meus irmãos, por estarem sempre presentes; À minha esposa, que me faz mais feliz a cada dia; e Aos meus filhos, Julia e Lucas, que me ensinaram a sorrir. 
"A questão principal deve ser como fortalecer os fundamentos legais do capitalismo de livre mercado: os direitos de propriedade dos acionistas e

proprietários de capital, ... Fraude e dolo são roubos de propriedade"

"The critical issue should be how to strengthen the legal base of free market capitalism: the property rights of shareholders and other owners of capital, ... Fraud and deception are thefts of property."

\begin{abstract}
Alan Greenspan
"Quando eu era jovem, eu achava que o dinheiro era a coisa mais importante na vida, agora que estou velho, eu sei que é"

"When I was young, I thought that money was the most important thing in life; now that I am old, I know it is"
\end{abstract}

Oscar Wilde 


\section{RESUMO}

O presente trabalho tem por objetivo fazer um apanhado dos modelos de remuneração comuns nas companhias brasileiras de capital aberto, com base nas informações divulgadas no âmbito das reformas instituídas pela Comissão de Valores Mobiliários, através das Instruções CVM no 480 e 481 de 2009. Para tanto, expõe a relevância do tema da remuneração do ponto de vista da teoria da agência e seus impactos na governança corporativa, elemento fundamental para proteção aos investidores. Também são apresentados detalhes sobre as formas de remuneração divulgadas por companhias de capital aberto de acordo com as normas administrativas vigentes, com ênfase nos mecanismos patrimoniais de contraprestação. Por fim, é apresentado um levantamento da distribuição de diferentes elementos de remuneração dos diretores e conselheiros de companhias de capital aberto divulgados para os exercícios de 2007 até 2009, bem como projeções para 2010.

\section{Palavras-chave}

Remuneração dos Administradores, Mercado de Capitais, Governança Corporativa, Estrutura de Propriedade, Companhias Abertas, Formulário de Referência. 


\section{SUMÁRIO}

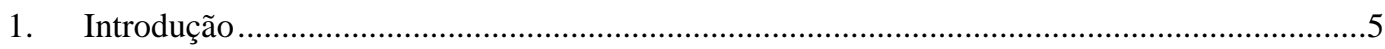

2. Teoria da agência e a origem do conflito de interesses............................................... 8

3. A estrutura de propriedade e a remuneração.................................................................11

4. Objetivos das políticas e práticas de remuneração da administração....................................14

4.1. A remuneração além da mera contraprestação............................................................15

4.2. O equilíbrio entre a busca por resultados e o crescimento de longo prazo para a

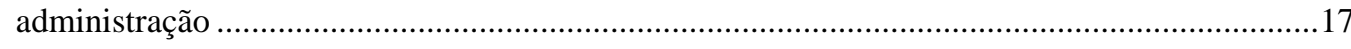

5. Modelos de remuneração da alta administração ..............................................................19

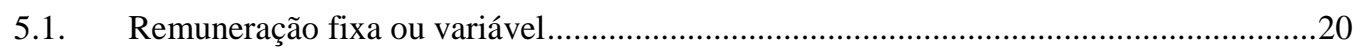

5.2. Remuneração voltada para o curto, médio ou longo prazo ..........................................20

5.3. Contraprestação financeira ou patrimonial ..............................................................22

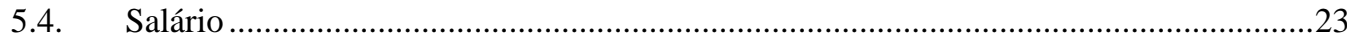

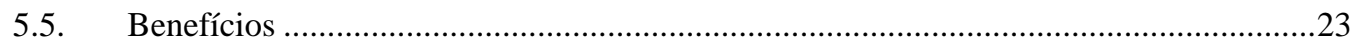

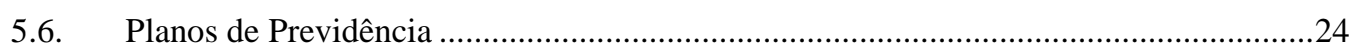

5.7. Bônus por desempenho e participação nos lucros........................................................24

5.8. Bônus por contratação ("hiring bonus") e desligamento ("golden parachute") ............25

5.9. Remuneração por participação em Comitês ...............................................................26

5.10. Remuneração por participação em reunião de Conselho de Administração ..............27

5.11. Remuneração através de opções de compra de ações ("stock options") ....................27

6. Planos de remuneração baseados em ações .....................................................................29

6.1. Custo da remuneração por opções para as companhias .............................................31

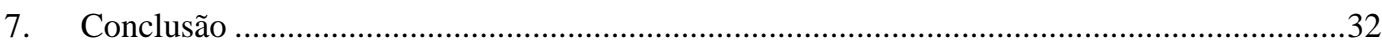

8. Anexo I - Remuneração dos administradores por órgão societário.......................................33

8.1. Remuneração dos administradores por órgão societário ..............................................33

8.2. Distribuição dos elementos de remuneração da diretoria estatutária .............................34

8.3. Lista das companhias que compõem o índice Bovespa .............................................36

9. Anexo II - Divulgação da remuneração dos administradores (Seção 13 do Formulário de

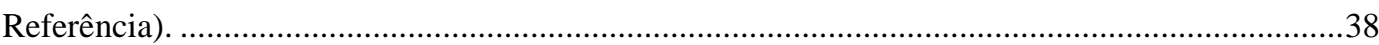

10. Anexo III - Relação entre valores em opções: preço de exercício e preço de outorga.......42

11. Anexo IV - Remuneração divulgada pelas companhias do Ibovespa para os exercícios de

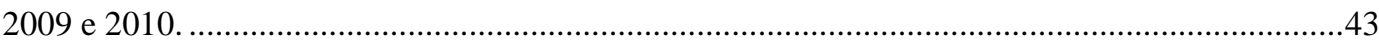

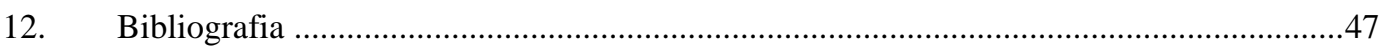




\section{Introdução}

A tendência recente de divulgação detalhada dos elementos que compõem a remuneração de administradores de companhias abertas reflete o fato que, como decorrência da crise financeira global que afeta as principais economias do mundo, as companhias passaram a enfrentar um problema de "legitimidade" frente ao público ${ }^{1}$. Apesar de existirem opiniões distintas quanto à relevância da remuneração dos administradores e sua contribuição para a crise mundial, nos últimos anos observa-se um aumento considerável da regulação acerca deste tema em diversos países, como nos Estados Unidos, no Reino Unido e, mais recentemente, no Brasil.

$\mathrm{O}$ assunto parece exercer especial interesse para a imprensa especializada, tendo em vista a sua facilidade de compreensão pelo grande público e a curiosidade que o tema desperta. Não é raro que sejam pagas a título de contraprestação por serviços prestados, quantias fabulosas aos administradores, muitas vezes sem que estas estejam vinculadas diretamente aos resultados ${ }^{2}$ de longo prazo. A publicação de matérias veiculando estes valores na imprensa também se tornou freqüente nos países onde foram adotadas regras impondo a divulgação das informações sobre remuneração.

Os doutrinadores nacionais de direito societário também manifestam preocupação sobre o tema da remuneração, tendo em vista a possibilidade da administração da companhia impor à assembléia geral a fixação de elevados honorários em seu favor ${ }^{3}$. A preocupação clássica dos juristas brasileiros ${ }^{4}$ com a

\footnotetext{
${ }^{1} \mathrm{O}$ embate em busca de legitimidade enfrentado pelas companhias abertas é um tema recorrente no noticiário especializado em países onde a crise econômica atual é mais severa. O tema foi desenvolvido também por Jennifer G. Hill, em "New Trends in the Regulation of Executive Remuneration".

2 Ao longo do texto os termos "resultado", "resultado operacional", "lucros" e "dividendos" são utilizados como referência comum ao desempenho financeiro da sociedade, sem que sejam feitas as corretas distinções para cada um destes elementos. Desta forma, dentro do escopo deste texto, os termos podem ser entendidos como sinônimos, similares à expressão "bottom-line" utilizada pela doutrina americana.

3 "Os abusos cometidos pelos diretores que, detendo o controle da sociedade, impunham à assembléia geral a fixação de elevados honorários em seu favor, esvaziando a conta de lucros a distribuir aos acionistas, foi sempre motivo de reclamação das minorias e tema preocupante dos especialistas." (REQUIÃO, 2010, p. 242)

${ }^{4}$ A preocupação com o desvio dos lucros e dividendos da companhia para pagamento de honorários excessivos foi regulada através dos limites impostos pelo art. $152, \S 1^{\circ}$ da Lei. 6.404/1976, que diz: "O estatuto da companhia que fixar o dividendo obrigatório em $25 \%$ (vinte e cinco por cento) ou mais do lucro líquido, pode atribuir aos administradores participação no lucro
} 
remuneração nas sociedades anônimas de capital aberto está geralmente associada ao modelo de propriedade concentrada típico das sociedades com controle definido. Isto pode ser identificado pelo tipo de abuso aos direitos dos minoritários que mais aparecem em textos de doutrinadores pátrios, que se preocupam com a fixação de elevados honorários pelos controladores como meio de desviar os lucros da empresa.

Para enfatizar a necessidade de divulgação das informações de remuneração do ponto de vista da manutenção do crescimento de longo prazo e preservação dos interesses dos acionistas, o capítulo dois do presente trabalho apresenta uma rápida introdução à teoria da agência e a origem do conflito de interesses entre agentes e principais. Como será elaborado posteriormente, a divulgação da remuneração dos administradores é essencial do ponto de vista da governança corporativa para maximizar a criação de valor e alinhar os interesses de administradores e acionistas.

Diferentes estruturas de propriedade impactam de formas distintas o gerenciamento das companhias abertas, sendo fator determinante para o direcionamento decisões das sociedades. Assim sendo, o capítulo três apresenta uma breve distinção entre os impactos da teoria da agência em companhias de controle concentrado ou disperso, enfatizando as diferenças entre cada modelo. Apesar da modelo de propriedade concentrada ser mais comum no Brasil por larga margem, as referências feitas ao longo do texto não restringem o impacto da teoria da agência a um tipo específico de estrutura de propriedade.

O alinhamento entre os interesses dos administradores e demais interessados no desempenho das companhias é apresentado no capítulo quatro do presente trabalho, que descreve as políticas e práticas de remuneração da administração. A relevância do tópico é essencial para a compreensão da maneira através da qual é possível se motivar os gestores da companhia na direção correta, além de complementar o entendimento da teoria da agência apresentado no capítulo anterior. 
O capítulo cinco relaciona cada um dos elementos que tipicamente compõem a remuneração da administração, fazendo alusão aos tipos de remuneração elencados pela regulamentação administrativa brasileira, publicada pela Comissão de Valores Mobiliários. Para tanto, são abordados cada um dos elementos utilizados como contraprestação aos serviços prestados pelos administradores, com referências aos itens do Formulário de Referência ${ }^{5}$ em que estes devem ser divulgados pelas companhias de capital aberto.

Dentre os objetivos da remuneração encontra-se o de maximizar o desempenho dos administradores, efeito possível através da instituição de prêmios. Os critérios para premiação do desempenho apresentam grande diversidade entre as empresas, e muitas vezes demandam dos estudiosos conhecimentos especializados sobre derivativos, em especial no que tange a remuneração em ações, ou patrimonial. Assim sendo, de modo a facilitar a compreensão de alguns conceitos típicos de finanças, o trabalho apresenta em seu capítulo seis uma análise sucinta dos pontos fundamentais acerca dos principais instrumentos de derivativos aplicados à remuneração, como opções de compra de ações.

Cabe enfatizar ainda que, as referências feitas ao longo do texto à administração da companhia devem ser entendidas como às pessoas investidas na função de administradores, ou seja, àquelas definidas assim pela legislação societária, sem distinção explícita ao papel do conselho de administração ou da diretoria estatutária ${ }^{6}$.

Na Grécia helênica, os vencedores dos jogos olímpicos recebiam coroas de louros e subiam no pódio, sendo inclusive homenageados com louros e poemas.

\footnotetext{
${ }^{5}$ O Formulário de Referência é um documento de divulgação eletrônica, instituído pelo art. 24 da Instrução CVM $\mathrm{n}^{\circ}$ 480/09, que, em sua seção 13 , trata do tema da remuneração dos administradores. O Anexo 13 da referida instrução determina o seu formato de apresentação, e o Ofício-Circular CVM/SEP/n ${ }^{\circ}$ 05/2010 disciplina o conteúdo de alguns de seus itens. O Formulário de Referência substituiu o antigo Formulário de Informações Anuais - IAN e visa à divulgação informações de toda sorte que diga respeito a emissores de valores mobiliários, incluindo companhias de capital aberto.

${ }^{6}$ As referência aos diretores estatutários e membros do conselho de administração podem ser encontradas também na legislação societária (Lei 6.404/1976), que, em seu art. 138 determina que a administração da companhia competirá, conforme dispuser o estatuto ao conselho de administração e à diretoria, ou somente à diretoria. Entretanto, vale ressaltar o que ensina Rubens Requião: “... a Comissão de Valores Mobiliários detém, porém a faculdade de determinar a adoção do conselho de administração pelas companhias abertas" (REQUIÃO; 2010; p. 229)
} 
As homenagens do passado tinham valor simbólico, assim como ainda são simbólicos alguns incentivos da atualidade. A grande maioria dos incentivos, no entanto, tem uma natureza de recompensa ou estímulo material. $\mathrm{O}$ mesmo pode ser dito da estrutura de remuneração estabelecida em algumas companhias abertas, onde os rendimentos elevados dos administradores servem também como estímulo aos demais executivos que almejam ascender na hierarquia da empresa.

A título de complementação, o Anexo I do presente trabalho apresenta um levantamento dos valores declarados pelas companhias abertas para a remuneração dos administradores. Os dados utilizados para esta análise foram divulgados através do através do Formulário de Referência e consideram somente as companhias que fazem parte do índice Bovespa, ou Ibovespa ${ }^{7}$, e representam as principais companhias com ações negociadas na BM\&FBovespa.

O presente trabalho pretende fazer um apanhado dos modelos de remuneração comuns nas companhias brasileiras de capital aberto, com base nas informações divulgadas no âmbito das reformas instituídas pela Comissão de Valores Mobiliários, através das Instruções CVM n 480 e 481 de 2009. Para tanto foram feitas diversas referências aos itens do Formulário de Referência, documento de divulgação eletrônica que, em sua seção 13 , trata do tema da remuneração dos administradores. Os itens do Formulário de Referência que tratam da remuneração dos administradores encontram-se listados taxativamente no Anexo II, conforme estabelecido pela referida norma administrativa.

\section{Teoria da agência e a origem do conflito de interesses}

Para melhor compreender o papel da remuneração como instrumento para evitar possíveis conflitos de interesse entre a administração de uma companhia e seus acionistas é essencial mencionar, ainda que brevemente, a teoria da agência. O desenvolvimento da teoria da agência, fruto dos trabalhos de Jensen e Meckling em 1976, encontra-se no cerne do pensamento moderno sobre governança

\footnotetext{
7 O índice Bovespa é o valor atual, em moeda corrente, de uma carteira teórica de ações constituída em 02.01.1968 (valor-base: 100 pontos), a partir de uma aplicação hipotética. Supõe-se não ter sido efetuado nenhum investimento adicional desde então, considerando-se somente os ajustes efetuados em decorrência da distribuição de proventos pelas empresas emissoras.
} 
corporativa, e foi amplamente recepcionado pelos estudiosos da matéria no Brasil e no mundo.

Por sua vez, o conceito de governança corporativa, apesar de controverso, pode ser entendido, de acordo com a definição proposta pela Comissão de Valores Mobiliários $^{8}$, como "o conjunto de práticas que têm por finalidade maximizar o desempenho de uma companhia ao proteger todas as partes interessadas, tais como investidores, empregados e credores, facilitando o acesso ao capital". $\mathrm{Ou}$ ainda, nas palavras de Machado Filho ${ }^{9}$, a governança corporativa trata da minimização de assimetrias e conflitos de interesse inerentes à delegação de poder.

A teoria da agência considera a empresa como um nexo de contratos entre fatores individuais de produção. Segundo ela, os contratos regem a relação entre o principal e o agente, em que certos poderes de decisão são delegados ao agente no ato da prestação de serviços ao principal. Ao considerar que as partes buscam a maximização de sua satisfação pessoal, caso o agente não haja no interesse do principal, instalando um conflito de agência, este se cerca de garantias para evitar um conflito de interesses.

Assim sendo, a teoria da agência analisa os conflitos existentes entre os principais (proprietários) e os agentes (administradores) considerando que os interesses dos primeiros nem sempre estão alinhados com o dos administradores. Ainda de acordo com a teoria, para amenizar estas divergências os proprietários devem tomar as seguintes medidas fundamentais: (i) estabelecer incentivos para que o agente aja em favor do principal; e (ii) monitorar os atos dos agentes.

A importância da remuneração da administração como mecanismo de alinhamento dos interesses dos administradores também encontra-se refletida nos códigos de governança corporativa. No Brasil, o Instituto Brasileiro de

\footnotetext{
${ }^{8}$ Ver cartilha de governança corporativa da Comissão de Valores Mobiliários.

${ }^{9}$ Ver Machado Filho, C. P. "Responsabilidade social e governança. O debate e as implicações.", São Paulo, Pioneira Thompson Learning, 2006
} 
Governança Corporativa ${ }^{10}$ incorporou a divulgação da remuneração de gestores e conselheiros em seu código de melhores práticas de governança corporativa ${ }^{11}$.

Desta forma, resta evidente a relevância que a remuneração possui, por ser esta um dos principais instrumentos de incentivo aos administradores, que, em seu papel de agente, devem orientar seus atos de acordo com os interesses dos acionistas (proprietários). Cabe enfatizar ainda que, se ambas as partes são maximizadores de utilidade, é perfeitamente plausível acreditar que o administrador nem sempre irá agir de acordo com os interesses dos acionistas.

Adicionalmente, os tipos de conflitos de interesse explicados pela teoria da agência possuem características que variam de acordo com a estrutura de propriedade de cada companhia. Neste sentido, enquanto nas companhias com estrutura de capital disperso o conflito contrapõe administradores e acionistas, nas com estrutura de propriedade concentrada eles surgem entre os acionistas majoritários e os minoritários. Esta diferença será explorada em maiores detalhes no próximo capítulo.

${ }^{10}$ O IBGC é uma das principais entidades que se preocupam com o tema da governança corporativa no Brasil, sendo responsável pela certificação de membros de conselhos de administração e fiscal. O objetivo do Instituto, conforme definido em seu Estatuto Social, é: "ser referência em Governança Corporativa, contribuindo para o desenvolvimento sustentável das organizações, influenciando os agentes sociais e estimulando a adesão aos valores e princípios de Governança Corporativa definidos pelo próprio Instituto."

11 "A remuneração dos conselheiros deve ser divulgada individualmente ou, ao menos, em bloco separado do montante relativo à remuneração da gestão" (IBGC; 2009; p. 40)

"A remuneração dos diretores deve ser divulgada individualmente ou, ao menos, em bloco separado do montante relativo ao Conselho de Administração" (IBGC; 2009; p. 57) 


\section{A estrutura de propriedade e a remuneração}

A composição acionária de uma companhia e a distribuição de suas ações determinam sua estrutura de propriedade, ou seja, a forma e a efetividade com que a vontade de seus proprietários se manifesta. As ações com direito a voto podem estar concentradas com um ou poucos acionistas, chamado de acionista controlador ou bloco de controle ${ }^{12}$, ou dispersa pelo mercado entre vários investidores. Diversos aspectos de gestão da sociedade são afetados pela estrutura de propriedades, entre eles encontra-se também a remuneração dos administradores.

Um conhecido estudo elaborado por Rafael La Porta envolvendo 27 países, incluindo o Brasil, demonstrou que existe a prevalência do modelo de estrutura de propriedade concentrada no mundo, com concentração entre grandes grupos familiares e o Estado ${ }^{13}$. O capital disperso de companhias abertas é um modelo comum em países anglo-saxões, como os Estados Unidos e o Reino Unido. Por outro lado, países do continente europeu, como França, Itália e Alemanha, caracterizam-se por forte concentração de propriedade e controle, assim como o Brasil.

Desta forma, é razoável que especial atenção seja dada pela doutrina americana ao modelo de propriedade de companhias com capital pulverizado ${ }^{14}$, caracterizadas pelo chamado controle administrativo, onde, na ausência da figura do acionista controlador a administração adquire papel preponderante, restando aos demais proprietários recorrer aos mecanismos de controle ${ }^{15}$ e regulação ${ }^{16}$ para

\footnotetext{
${ }^{12}$ A Lei 6.404/1976 define controlador como: “Art. 116. Entende-se por acionista controlador a pessoa, natural ou jurídica, ou o grupo de pessoas vinculadas por acordo de voto, ou sob controle comum, que: (a) é titular de direitos de sócio que lhe assegurem, de modo permanente, a maioria dos votos nas deliberações da assembléia-geral e o poder de eleger a maioria dos administradores da companhia; e (b) usa efetivamente seu poder para dirigir as atividades sociais e orientar o funcionamento dos órgãos da companhia."

${ }^{13}$ Para referência sobre a composição acionária de companhias no mundo ver Rafael La Porta, Law and Finance, "Journal of Political Economy", v. 106, p. 1113-1155, 1998.

${ }^{14}$ Diferenças na estrutura de propriedade das empresas ocasionam diferenças na modalidade dos escândalos corporativos perpetrados. A propriedade dispersa, comum nos países anglo-saxões, cria incentivos para os executivos manipularem os lucros visando uma maior remuneração pessoal. Já a propriedade concentrada, mais comum na Europa continental e no Brasil, cria incentivos para os controladores realizarem operações obscuras visando à extração de benefícios privados do controle. Para mais detalhes sobre a estrutura de propriedade em companhias ver John Coffee, "A Theory of corporate scandals: Why the U.S. and Europe differ", Columbia Law and Economics Working Paper $n^{\circ}$ 274, 2005.

${ }^{15} \mathrm{O}$ controle interno da companhia é exercido por todos os órgãos societários previstos pela Lei 6.404/1976, incluindo o conselho de administração, o conselho fiscal e a assembléia geral.
} 
evitar condutas abusivas. Entretanto, em companhias onde o modelo de propriedade é marcado pela presença de controle majoritário, com um controlador ou grupo de controle definido, a remuneração dos administradores pode levar a distorções de tipos diferentes que as encontradas em companhias com capital pulverizado $^{17}$.

As companhias brasileiras, em sua grande maioria, apresentam forte concentração das ações com direito a voto, com ausência quase total de empresas com estrutura de capital pulverizada ${ }^{18}$. Apresentam, portanto, estrutura de propriedade concentrada, mais próxima dos modelos encontrados na Europa continental. Esta concentração do poder de decisão leva, por sua vez, a uma diferenciação do problema tratado pela doutrina americana quando considera a teoria da agência, na medida em que o potencial conflito ocorre entre o acionista controlador e os minoritários, uma vez que os administradores muitas vezes agem como prepostos dos controladores ${ }^{19}$.

Segundo Calixto Salomão Filho, além desta grande concentração acionária, a estrutura de propriedade do controle das empresas brasileiras: (i) é caracterizado pelo controle familiar, compartilhado, ou exercido por multinacionais; (ii) os acionistas minoritários são pouco ativos e seus interesses não são completamente conhecidos; e (iii) há alta sobreposição entre propriedade acionária e gestão executiva ${ }^{20}$. Por outro lado, recentemente, com a evolução do mercado de capitais no Brasil, houve o surgimento de algumas exceções a regra do controle majoritário, com algumas empresas optando por dispersar grande parte ou mesmo a totalidade de seu capital entre inúmeros investidores na bolsa de

\footnotetext{
${ }^{16}$ A regulação a que as companhias estão sujeitas pode ter origem mandatória ou voluntária. Regulação mandatória decorre da lei em sentido amplo, incluindo os atos de órgãos administrativos a que a companhia esteja sujeita, como a CVM, o Banco Central ou a SUSEP, por exemplo. Por outro lado, a regulação voluntária pode se originar de associações e acordos que a companhia seja signatária, por exemplo, em iniciativas como os diferentes níveis de governança corporativa definidos pela BMF\&Bovespa (Novo Mercado, Nível 1 e Nível 2).

17 A estrutura de capital dispersa, também chamado de "free-float", pode ser definida como a parcela de capital que as companhias possuem sendo negociada na bolsa de valores, e, portanto, fora do bloco de controle. $\mathrm{O}$ art. 137 da Lei 6.404/76 define o termo por exclusão, a saber: "dispersão, quando o acionista controlador, a sociedade controladora ou outras sociedades sob seu controle detiverem menos da metade da espécie ou classe de ação;"

18 Para referências sobre as estruturas de capital nas companhias brasileiras ver Alexandre di Miceli da Silveira. Governança Corporativa no Brasil e no Mundo, Rio de Janeiro, Elsevier, 2010

${ }^{19}$ Para referências sobre a estrutura de capital e seu impacto na administração ver

${ }^{20}$ Ver Calixto Salomão Filho, O Novo Direito Societário, 2a edição, São Paulo, Malheiros, 2002, p. 63-64.
} 
valores, como foi o caso das Lojas Renner S.A., da Totvs S.A. e a Diagnósticos da América S.A..

Portanto, estudos sobre a teoria da agência e o impacto dos conflitos de interesses dentro de uma companhia podem ter enfoques distintos dependendo da experiência que o autor do texto pretende enfatizar, seja a de mercados caracterizados pelo controle concentrado ou disperso. Esta distinção é necessária para a adequação das idéias de autores estrangeiros e sua correta interpretação à realidade brasileira. 


\section{Objetivos das políticas e práticas de remuneração da administração}

O administrador, como agente responsável pela condução do dia-a-dia da companhia, recebe a delegação de representar os interesses dos acionistas, proprietários do negócio. Este dever do administrador vai além daquele atribuído pelo empregador ao empregado, trata-se de um conjunto de deveres para com toda a sociedade, podendo afirma-se que o primeiro destes é o de bem administrá-la ${ }^{21}$.

O art. 152 da Lei $6.404 / 76^{22}$ determina que a fixação da remuneração dos administradores cabe à assembléia geral que deve levar em conta suas responsabilidades, o tempo dedicado às suas funções, sua competência e reputação profissional e o valor dos seus serviços no mercado. Vê-se com isso a relevância que o legislador pátrio dedicou ao assunto, determinando que sua deliberação seja feita diretamente pelo órgão máximo da sociedade.

Ainda que o administrador tenha sido apontado para exercer a função pelo controlador da companhia, uma vez investido nesta função seus atos passam a atingir todos os acionistas, os credores, os empregados e demais interessados na administração da empresa. A doutrina americana chama estas pessoas interessadas na administração da companhia genericamente de "stakeholders",23.

Conforme se pode concluir do capítulo anterior, o objetivo principal das políticas e práticas de remuneração da administração pode ser definido como o alinhamento dos interesses dos administradores aos dos acionistas ${ }^{24}$. Entretanto, este alinhamento pode não ser algo elementar, tendo em vista que diferentes acionistas podem trabalhar com horizontes variados de tempo, taxas de juros e

\footnotetext{
21 "Os administradores têm vários deveres para com a sociedade, podendo-se afirmar que o primeiro de todos esses deveres é o de bem administrá-la; deve o administrador agir com competência, eficiência e honestidade que seriam de se esperar de um homem "ativo e probo" que estivesse a cuidar de seu próprio negócio.” (BORBA, 2010, p. 413)

22 "Art. 152. A assembléia-geral fixará o montante global ou individual da remuneração dos administradores, inclusive benefícios de qualquer natureza e verbas de representação, tendo em conta suas responsabilidades, o tempo dedicado às suas funções, sua competência e reputação profissional e o valor dos seus serviços no mercado." (Lei 6.404/76)

${ }^{23} \mathrm{O}$ termo "stakeholder", amplamente utilizado pela doutrina americana, se refere genericamente às pessoas que tenham algum interesse nos negócios da companhia, incluindo administradores, empregados, acionistas, fornecedores, credores, clientes, reguladores e quaisquer outros grupos ou indivíduos afetados pelos atos da empresa.

${ }^{24}$ Para alinhamento de interesses e o papel da administração ver Alberto Chilosi e Mirella Damiani "Stakeholders vs. Shareholders in Corporate Governance", texto eletrônico disponível em [http://ssrn.com/abstract=975293]
} 
propensão a suportar riscos. Assim sendo, a subjetividade e o gerenciamento de interesses diversos pode afetar a estratégia temporal que uma empresa adota para maximizar seus lucros.

Exemplificando, um acionista que resolve fazer um investimento em uma companhia para depois retornar ao seu país de origem com os lucros da operação pode ter um horizonte de tempo mais curto do que um fundo de pensão. Isto poderia levar a administração alinhada aos interesses dos acionistas a tomar decisões diferentes em matérias cruciais do ponte de vista financeiro, como a forma de financiamento de projetos ou o momento ideal para a alienação de participações ou ativos relevantes.

Entretanto, podemos dizer, de maneira geral, que o alinhamento dos interesses da administração leva à geração de valor aos acionistas da empresa considerados em conjunto. Esta geração de valor é normalmente mensurada através do pagamento de dividendos e do aumento no valor das cotações das ações da companhia negociadas nas bolsas de valores. Cabe ressaltar, entretanto, que diversos fatores externos à companhia influenciam a cotação dos papéis negociados em bolsa.

Portanto, podemos dizer que, em linha com o que ensina a teoria da agência e as melhores práticas de governança corporativa, as políticas e práticas de remuneração da administração adotadas por uma companhia devem buscar o alinhamento dos interesses dos acionistas, controladores e minoritários, credores, empregados e demais interessados na gestão correta dos negócios da entidade ${ }^{25}$.

\subsection{A remuneração além da mera contraprestação}

A legislação trabalhista ${ }^{26}$ define a remuneração como o conjunto de prestações recebidas pelo empregado em razão de serviços realizados, seja em dinheiro ou utilidades, proveniente dos empregadores ou de terceiros. Nesse sentido, o termo remuneração é gênero que inclui todas as contraprestações

\footnotetext{
25 "O objetivo é que a remuneração seja uma ferramenta efetiva de alinhamento dos interesses dos diretores com os da organização.” (IBGC; 2009; p. 56)

${ }^{26}$ Nesse sentido ver art. 457 e seguintes da Consolidação das Leis do Trabalho.
} 
recebidas pelo empregado por seu serviço, como salários, benefícios e todas as demais vantagens e valores pagos pelo empregador.

Por outro lado, as relações entre as companhias e seus administradores apresentam natureza comercial e não trabalhista ${ }^{27}$; os chamados diretoresempregados, ou seja, os empregados que se elevam à posição de diretores têm o contrato de trabalho suspenso enquanto exercem a função de diretores ${ }^{28}$. Assim sendo, ao considerarmos a remuneração da administração de uma companhia, devemos atentar para os aspectos inerentes a uma relação comercial, que, quando comparada às restrições impostas pela legislação trabalhista, possibilita maior liberalidade em sua composição às partes contratantes.

Cabe notar ainda que, a remuneração de administradores geralmente adquire características que ultrapassam sua função primordial de garantir a subsistência do agente. A competição, a especialização e a exigência constante de se criar valor para os acionistas impõem a criação de modelos remuneratórios que maximizem o desempenho dos administradores, além de manter seus interesses alinhados aos dos proprietários.

Em princípio, entende-se por desempenho ${ }^{29}$ no trabalho como o resultado que uma pessoa consegue com a aplicação de algum esforço. O desempenho é positivo quando o resultado cria benefícios para a própria pessoa, o grupo ou organização para qual ela trabalha. O desempenho na realização de qualquer tipo de tarefa ou objetivo é influenciado por forças chamadas motivos. São as forças que produzem a motivação para o trabalho.

Resta evidente que o desempenho e dedicação dos administradores é fator determinante para a geração de resultados da sociedade. Entretanto, os critérios de aferição do desempenho excepcional podem variar significativamente, em

\footnotetext{
27 "Qual a natureza do vínculo entre diretor e sociedade? As características da vinculação levam a considerar que se trata de um contrato de prestação de serviço, sem relação de dependência ou subordinação (o que exclui seja relação de emprego); é um funcionário social que integra um órgão com atribuições e funções próprias frente aos demais órgãos da companhia." (LAZZARESCHI NETO, 2010, p. 338)

${ }^{28}$ Para a natureza comercial da relação entre os administradores e a companhia ver sentença do Recurso Extraordinário n ${ }^{\circ}$ 100531-SP do Supremo Tribunal Federal.

${ }^{29}$ Para mais sobre desempenho e motivação ver, Antonio Cesar Maximiano, "Introdução à Administração", 6ª edição, p. 267-287, São Paulo, Atlas, 2004
} 
especial para as posições de gestão, onde o resultado final pode ser mais importante que o comprometimento pessoal.

No caso específico da avaliação do desempenho dos administradores de companhias abertas, a exigência de divulgação de informações possibilita a utilização pelo mercado de elementos quantitativos para mensurar sua eficiência. Assim sendo, critérios objetivos para compensação dos administradores podem ser estabelecidos através de dados contábeis auditados, como aumentos de lucro líquido, de lucro operacional, da receita operacional, ou através de índices compostos como o LAJIDA ${ }^{30}$ ("lucro antes de juros, impostos, depreciações e amortizações") ou o LAJIR ("lucro antes de juros e impostos"), entre outros.

Por todo o exposto, vê-se claramente que a remuneração da administração é um tema que apresenta especialidades do ponto de vista do ordenamento jurídico e da doutrina, com potencial de impactar os resultados operacionais que a sociedade gera para seus sócios. Esta preocupação se torna ainda mais relevante quando se pensa na manutenção de lucros a longo prazo.

\subsection{0 equilíbrio entre a busca por resultados e o crescimento de longo prazo para a administração}

O crescimento sustentável da companhia no longo prazo, bem como a geração constante de resultados operacionais positivos que gerem ganhos aos acionistas, pode por vezes ser deixado em segundo plano pelo administrador que reage a incentivos de um plano de remuneração mal elaborado ${ }^{31}$. Este tema é objeto de diversos trabalhos na doutrina americana, onde o papel do gestor na companhia com capital disperso influi de maneira pode influir nas estratégias financeiras a serem tomadas.

\footnotetext{
${ }^{30}$ Cabe ressaltar que as fórmulas utilizadas no cálculo de índices compostos como o LAJIDA e o LAJIR variam de acordo com as políticas contábeis utilizadas pelas companhias. Assim sendo, uma empresa pode reconhecer em seus cálculos receitas advindas de operações não recorrentes, enquanto outra considera apenas o lucro operacional. Para maiores informações sobre esta dificuldade ver o Edital de Audiência Pública SNC No 13/2010, publicado pela CVM em 18 de outubro de 2010.

${ }^{31} 31$ Para detalhes sobre planos de incentivos de longo prazo ver Lucian A. Bebchuk e Jesse M. Fried, "Paying for long-term performance", University of Pennsylvania Law Review, Vol. 158, p. 1915-1959, 2010.
} 
Desta forma, existe o risco para companhias que não possuem um majoritário definido de que a administração busque maximizar sua remuneração através de escolhas que impactarão a as finanças da companhia no longo prazo. Daí se infere, portanto, que o desempenho dos administradores está ligado, ainda que indiretamente, à estrutura de capital da companhia.

O crescimento de longo prazo deve ser estimulado por mecanismos de remuneração de longo prazo, como os planos de remuneração baseados em ações e opções de compra de ações. Tais planos podem ter estruturas complexas e serão detalhados posteriormente. Por enquanto resta saber que, de forma a manter o incentivo da administração e o alinhamento com os acionistas, não basta incrementar a quantidade de ações disponíveis no plano.

Em um estudo que gerou grande discussão nos meios acadêmicos, Mock propôs que a parcela de ações detidas pelos administradores influi diretamente na valorização das ações de uma companhia. Assim sendo, quando os gestores detinham entre 0 e $5 \%$ do capital social existia tendência de valorização, mas quando este montante estava entre 5 e $25 \%$ esta valorização diminuía, voltando a crescer em quando a participação era maior que $25 \%$. Uma possível interpretação para este estudo é que a motivação é substituída pela inércia e entrincheiramento da administração na companhia. Posteriormente, quando a parcela de se aproxima de níveis mais elevados, a preocupação do gestor passa se assemelhar ao do acionista controlador ${ }^{32}$.

\footnotetext{
32 "a firm value increases with managerial ownership if managers own between 0 and $5 \%$ of the firm's equity, decreases if managers own between 5 and $25 \%$, and increases again (weakly) for holdings above $25 \%$. One interpretation of their findings is that the initial positive effect reflects improving incentives, and the subsequent negative effect increasing managerial entrenchment." (MORCK; 1988; p. 293-315)
} 


\section{Modelos de remuneração da alta administração}

Em termos gerais, a remuneração dos diretores e conselheiros de uma companhia pode ser compreendida como a contraprestação por serviços prestados por estes indivíduos em benefício da empresa onde trabalham ou grupo econômico que estão associados. Diversas formas de remuneração foram desenvolvidas pelo mercado para manter os interesses de executivos e administradores em linha com os objetivos dos acionistas.

É importante enfatizar que, a teoria mais aceita entende que os valores dos prêmios por desempenho não garantem o alinhamento dos interesses entre a administração e os proprietários, sendo mais relevante a forma como estes são pagos. Assim sendo, o mais importante para a consecução dos objetivos dos proprietários é a definição de critérios claros para premiação, e não o mero incremento dos valores a serem recebidos ${ }^{33}$. Portanto, torna-se fundamental para os acionistas a compreensão detalhada dos planos de remuneração e seus impactos no comportamento futuro dos administradores.

Conforme dito anteriormente, a divulgação da remuneração da administração de companhias abertas tornou-se mandatória no Brasil com a publicação da Instrução $\mathrm{CVM} \mathrm{n}^{\circ}$ 480/2009, que, em seu art. 24 instituiu o Formulário de Referência, documento eletrônico que substituiu o Formulário de Informações Anuais - IAN, e cujo conteúdo encontra-se definido pelo Anexo 24 da referida norma. A seção 13 do Formulário de Referência trata exclusivamente da remuneração da administração.

A categorização dos elementos de remuneração e sua fundamentação tratada no restante deste capítulo buscam seguir o entendimento presente nas instruções recém publicadas pela CVM para divulgação de informações referentes à remuneração da administração ${ }^{34}$, bem como suas normas administrativas complementares, que regularam o conteúdo das informações prestadas.

\footnotetext{
${ }^{33}$ Para o impacto de modelos de remuneração no comportamento dos administradores ver Jensen e Murphy, "CEO Incentives - It's not how much you pay, but how", Harvard Business Review, $\mathrm{N}^{\circ} .3$, 1990, p. 138-153.

${ }^{34}$ Instruções CVM no 480 e 481 de 2009; Ofício-Circular CVM/SEP/nº 01/2010; Ofício-Circular $\mathrm{CVM} / \mathrm{SEP} / \mathrm{n}^{\circ} 05 / 2010$.
} 


\subsection{Remuneração fixa ou variável}

Nas palavras do jurista Modesto Carvalhosa ${ }^{35}$, a remuneração fixa é aquela deliberada pela assembléia geral e correspondente à contraprestação dos serviços prestados pelo administrador à companhia. Neste sentido, conforme ensina o eminente jurista, é essencial que exista equivalência jurídico-econômica entre o valor pago e os serviços efetivamente prestados.

Por outro lado, a parcela variável da remuneração não é paga em função dos meramente dos serviços prestados pelo administrador à companhia e, sim, sobre os resultados atingidos naquele exercício. A parcela variável da remuneração inclui proventos referentes à participação nos lucros da companhia, bônus e demais valores variáveis, podendo ser estatutárias ou deliberadas em assembléia geral.

Diferentemente da parcela fixa da remuneração, os valores variáveis recebidos pelos administradores possuem caráter de prêmio por desempenho atingido, podendo ser fixados em função de metas pessoais, de grupo ou da empresa.

Por fim, a Instrução CVM no 480/09 separa a remuneração em fixa e variável, devendo a primeira ser apresentada no item 13.2 e a segunda no item 13.3 do Formulário de Referência.

\subsection{Remuneração voltada para o curto, médio ou longo prazo}

A experiência do mercado ${ }^{36}$ mostra que existe a tendência de se categorizar os elementos que compõem a remuneração dos administradores de várias maneiras, sendo comum a segmentação por lapso temporal. Assim, os planos de remuneração das principais companhias brasileiras podem ser segmentados em elementos voltados para o curto, médio e longo prazo ${ }^{37}$.

\footnotetext{
35 “a remuneração fixa - direta e indireta - é aquela deliberada pela assembléia geral e correspondente à contraprestação dos serviços prestados pelo administrador à companhia. Deve ter equivalência jurídico-econômica com o valor objetivo dos serviços efetivamente prestados". (CARVALHOSA, 1998. p. 222)

${ }^{36}$ Definições para as remunerações de curto, médio e longo prazo são utilizadas de maneiras distintas nos Formulários de Referência das companhias abertas, com os elementos que as compõem variando conforme a política interna de cada empresa.

${ }^{37}$ A classificação temporal proposta foi apresentada pela consultoria especializada em recursos humanos Towers Watson, apresentação "Práticas e tendências em remuneração de administradores e executivos", Expomoney, São Paulo , em 26 de março de 2010.
} 
A remuneração de curto prazo inclui os valores recebidos dentro de um mesmo exercício social ou ciclo operacional, e, portanto, anteriores à publicação dos resultados nas demonstrações financeiras. Nela se incluem os salários e os benefícios recebidos pelos administradores, podendo ainda incluir parcela variável conferida pela consecução de objetivos e metas definidas previamente.

Em regra, os rendimentos relacionados à remuneração de curto prazo compõem o valor fixo e mínimo a que os administradores têm direito pela prestação de seus serviços. Ademais, se ao empregado que ascende à posição de administrador são asseguradas as condições de seu contrato de trabalho, mantémse as provisões da relação trabalhista. Neste caso, sujeita-se a empresa à incidência de Imposto de Renda na fonte, e contribuições para o INSS e FGTS sobre estes elementos da remuneração ${ }^{38}$.

A remuneração de médio prazo é composta pelos valores recebidos após a publicação dos resultados do exercício anterior, ou seja, depois que a atuação dos administradores se torna de conhecimento dos acionistas. A remuneração de médio prazo geralmente inclui parcelas variáveis de natureza financeira, com o pagamento de gratificações por desempenho, também chamados de bônus, além da participações nos lucros da companhia.

Por outro lado, a remuneração de longo prazo é aquela cujos benefícios ao administrador somente se farão sentir após diversos exercícios sociais, e caracteriza-se pela eventual participação no patrimônio da companhia, através de planos de remuneração baseados em ações ("equity compensation"). ${ }^{39} \mathrm{O}$ benefício maior para os acionistas que deriva da remuneração de longo prazo é a retenção de pessoal estratégico para o desenvolvimento da companhia. Assim sendo, planos de remuneração baseado em ações e opções de compra de ações têm por objetivo a retenção de administradores capazes de gerar resultados operacionais positivos de maneira continuada, maximizando o valor das ações da companhia $^{40}$.

\footnotetext{
${ }^{38}$ Ver Tavares Borba, "Direito Societário”, p. 410, 12ª edição, Rio de Janeiro, Renovar, 2010.

${ }^{39}$ Para detalhes sobre planos de incentivos de longo prazo ver Lucian A. Bebchuk e Jesse M. Fried, "Paying for long-term performance", University of Pennsylvania Law Review, Vol. 158, p. 1915-1959, 2010.

40 "Equity compensation arrangements should, therefore, provide executives with incentives to maximize long-term value, not the short-term stock price." (BEBCHUK \& FRIED, 2010, p. 6)
} 
É importante mencionar que esta classificação temporal para a remuneração, apesar de amplamente utilizada pelo mercado ${ }^{41}$, encontra variação entre os autores especializados, mesmo derivando de alguns conceitos financeiros e contábeis importantes. Utiliza-se neste trabalho o conceito análogo à definição contábil de curto prazo ${ }^{42}$, enquanto o longo prazo incluirá somente os valores de natureza patrimonial. Ao médio prazo admite-se uma combinação de elementos financeiros e patrimoniais.

\subsection{Contraprestação financeira ou patrimonial}

Outra forma de categorizar os elementos do plano de remuneração em uma companhia diz respeito ao tipo de contraprestação recebida pelos administradores, podendo ser de natureza financeira ou patrimonial. Esta distinção, mais comum na doutrina americana, é muito útil para a análise dos planos de remuneração mais complexos, onde a parcela patrimonial, geralmente composta por ações ou opções de compra de ações, pode constituir parcela significativa dos pagamentos por serviços prestados pela administração.

Neste sentido, a contraprestação financeira abarca todos os pagamentos em moeda que o administrador tem direito, como salários e bônus, podendo ser fixos ou variáveis. Por outro lado, a contraprestação patrimonial pode ser definida como a remuneração feita pelo recebimento de um direito sobre um ativo qualquer, seja ele potencial ou concreto, como a outorga de ações ou de opções de compra de ações, por exemplo.

Por outro lado, a contraprestação patrimonial ("equity compensation”) engloba os pagamentos realizados em participação no patrimônio das empresas, como ações e opções de compra de ações. Não se trata do conceito trabalhista do salário in natura ou utilidade, visto que carece a contraprestação patrimonial dos requisitos de habitualidade e gratuidade.

\footnotetext{
${ }^{41}$ Definições para as remunerações de curto, médio e longo prazo são utilizadas de maneiras distintas nos Formulários de Referência das companhias abertas, com os elementos que as compõem variando conforme a política interna de cada empresa.

${ }^{42}$ Para maiores detalhes sobre as definições contábeis de curto e longo prazo e ciclo operacional ver José Carlos Marion, "Contabilidade Empresarial”, p. 269-271, 13ª edição, São Paulo, Atlas, 2008.
} 
O papel da contraprestação patrimonial como ferramenta de estímulo à criação de valor pela administração é amplamente defendida pela doutrina especializada, assim como a estrutura de propriedade das companhias onde os administradores atuam $^{43}$. A remuneração patrimonial é chamada pela norma administrativa da CVM de remuneração baseada em ações.

\subsection{Salário}

O salário encontra-se definido pela doutrina trabalhista como espécie do gênero remuneração. Também para efeitos da remuneração dos administradores ele pode ser entendido desta forma, podendo ser definido, de acordo com as práticas trabalhistas, seja por hora, dia, semana ou mês ${ }^{44}$. No âmbito da nova regulamentação de divulgação de informações sobre remuneração da administração das companhias de capital aberto, as informações sobre o salário dos administradores devem estar presentes no item 13.2 do Formulário de Referência.

É importante que se diga que o salário, assim como todos os valores indicados para a remuneração fixa ou variável, deve constar do Formulário de Referência sempre em moeda corrente ${ }^{45}$, mesmo quando a remuneração atribuída a título de bônus ou participação nos resultados seja fixada com base em outro critério, como por exemplo, número de salários.

\subsection{Benefícios}

A remuneração através de benefícios é feita através da disponibilização de serviços e bens custeados pela empresa direcionados à manutenção dos administradores e suas famílias. Nesta categoria estão incluídos, por exemplo, o acesso a cartões corporativos, automóveis da empresa, moradia e demais utilidades.

O Ofício-Circular/CVM/SEP/N05/2010 determina que as companhias descrevam, no item 13.1 do Formulário de Referência, os benefícios diretos e

\footnotetext{
${ }^{43}$ Para detalhes sobre planos de incentivos de longo prazo ver Lucian A. Bebchuk e Jesse M. Fried, "Paying for long-term performance", University of Pennsylvania Law Review, Vol. 158, p. 1915-1959, 2010.

${ }^{44}$ Para maiores informações sobre a conceituação de salário ver Sergio Martins, Direito do Trabalho, $17^{\mathrm{a}}$ ed., São Paulo: Atlas, 200, p. 219.

${ }^{45}$ Ver Ofício-Circular CVM/SEP/n ${ }^{\circ}$ 05/2010.
} 
indiretos, divulgando seus componentes. Neste sentido, entende-se por benefícios diretos ou indiretos o direito a planos de previdência privada, assistência médica, odontológica, seguro de vida, automóvel, e etc.

A informação sobre benefícios também deve constar do item 13.2 do Formulário de Referência, que descreve a parcela fixa a ser paga aos administradores consolidada por órgão societário.

\subsection{Planos de Previdência}

Os planos de previdência também devem ser divulgados através do Formulário de Referência, devendo a administração divulgar as informações sobre eles no item 13.10 do documento. O Ofício-Circular/CVM/SEP/N05/2010 estabeleceu um formato padronizado para envio das informações, conforme a tabela abaixo:

\begin{tabular}{|l|l|l|}
\hline & $\begin{array}{c}\text { Conselho de } \\
\text { Administração }\end{array}$ & $\begin{array}{c}\text { Diretoria } \\
\text { Estatutária }\end{array}$ \\
\hline $\mathrm{N}^{\circ}$ de membros & & \\
\hline Nome do plano & & \\
\hline $\begin{array}{l}\text { Quantidade de administradores que reúnem condições para se } \\
\text { aposentar }\end{array}$ & & \\
\hline Condições para se aposentar antecipadamente & & \\
\hline $\begin{array}{l}\text { Valor acumulado atualizado das contribuições acumuladas até o } \\
\text { encerramento do último exercício social, descontada a parcela } \\
\text { relativa às contribuições feitas diretamente pelos administradores }\end{array}$ & & \\
\hline $\begin{array}{l}\text { Valor total acumulado das contribuições realizadas durante o último } \\
\text { exercício social, descontada a parcela relativa a contribuições feitas } \\
\text { diretamente pelos administradores }\end{array}$ & & \\
\hline Possibilidade de resgate antecipado e condições & & \\
\hline
\end{tabular}

\subsection{Bônus por desempenho e participação nos lucros}

A participação dos administradores nos lucros da companhia encontra-se prevista pelo art. 152, $\S 2^{\circ}$ da Lei 6.404, que determina que: "os administradores somente farão jus à participação nos lucros do exercício social em relação ao qual for atribuído aos acionistas o dividendo obrigatório, de que trata o artigo 202". Assim sendo, existindo lucro a ser distribuído na forma de dividendos, os administradores participarão de sua distribuição.

A remuneração variável de natureza financeira foi reunida no item 13.3 do Formulário de Referência, que a discrimina em bônus e participação nos 
resultados. A distinção entre as duas figuras é comum no mercado, tendo em vista que o bônus é geralmente associado ao cumprimento de algum objetivo ou meta, enquanto a participação no resultado deriva dos lucros que a companhia aferiu no período em questão.

O Ofício-Circular/CVM/SEP/N ${ }^{\circ} 05 / 2010$ determina que a apresentação destas informações deve ser feito seguindo o formato da tabela abaixo:

\begin{tabular}{|l|l|l|l|l|}
\hline & $\begin{array}{c}\text { Conselho de } \\
\text { Administração }\end{array}$ & $\begin{array}{c}\text { Diretoria } \\
\text { Estatutária }\end{array}$ & $\begin{array}{c}\text { Conselho } \\
\text { Fiscal }\end{array}$ & Total \\
\hline No de membros & & & & \\
\hline Bônus & & & & \\
$\begin{array}{c}\text { Valor mínimo previsto no plano de } \\
\text { remuneração }\end{array}$ & & & & \\
$\begin{array}{c}\text { Valor máximo previsto no plano de } \\
\text { remuneração }\end{array}$ & & & & \\
$\begin{array}{c}\text { Valor previsto no plano de remuneração, caso } \\
\text { as metas fossem atingidas }\end{array}$ & & & & \\
\hline $\begin{array}{c}\text { Valor efetivamente reconhecido no resultado } \\
\text { dos 3 últimos exercícios sociais }\end{array}$ & & & & \\
\hline Participação nos resultados & & & \\
\hline $\begin{array}{c}\text { Valor mínimo previsto no plano de } \\
\text { remuneração }\end{array}$ & & & & \\
\hline $\begin{array}{c}\text { Valor máximo previsto no plano de } \\
\text { remuneração }\end{array}$ & & & & \\
\hline $\begin{array}{c}\text { Valor previsto no plano de remuneração, caso } \\
\text { as metas fossem atingidas }\end{array}$ & & & & \\
\hline $\begin{array}{c}\text { Valor efetivamente reconhecido no resultado } \\
\text { dos 3 últimos exercícios sociais }\end{array}$ & & & & \\
\hline
\end{tabular}

\subsection{Bônus por contratação ("hiring bonus") e desligamento ("golden parachute")}

O bônus por contratação ("hiring bonus") é o pagamento antecipado feito ao administrador recém contratado. É uma ferramenta que aumenta a capacidade de atração da empresa para profissionais altamente capacitados e disputados pelo mercado, bem como ajuda a contrabalançar possíveis multas por desligamento antecipado a que estejam sujeitos estes administradores. Os bônus por contratação têm por objetivo compensar os executivos contratados por benefícios e incentivos que são perdidos no desligamento do emprego anterior, assim como pelo risco que a mudança pode gerar. 
A divulgação das informações sobre bônus de contratação são geralmente incluídas pelas companhias no Formulário de Referência no item 13.16, que permite que sejam tornadas públicas outras informações não previstas na estrutura do documento, entretanto sua divulgação é facultativa. Não foram encontrados valores divulgados pelas companhias para bônus por desligamento na análise dos Formulários de Referência incluída no Anexo II deste trabalho.

A saída de um administrador competente e capaz de entregar resultados palpáveis pode contrariar o interesse dos acionistas. Assim sendo, pode parecer estranho que os pacotes de remuneração incluam ferramentas como bônus por desligamento ("golden parachute"), pagos no momento em que o administrador deixa a companhia.

Por outro lado, apesar de não auxiliar na retenção destes executivos, existem casos em que garantias como esta podem ser fundamentais para atração de profissionais disputados pelo mercado. Exemplos desta prática podem ser encontrados em companhias que enfrentam dificuldades financeiras que colocam em dúvida sua solvência, ou que atuam em mercados altamente competitivos em situações desfavoráveis ${ }^{46}$.

Os bônus por desligamento deve ser informado pelas companhias no item 13.12 do Formulário de Referência, indicando as implicações que a destituição do cargo ou aposentadoria podem ter para a empresa.

\subsection{Remuneração por participação em Comitês}

Comitês são estruturas de deliberação interna de cada sociedade que atuam para endereçar tópicos determinados como auditoria, de risco, financeiro e de remuneração ou quaisquer outros que a gestão da companhia considerar relevantes. Os comitês podem ser previstos nos Estatutos Sociais das companhias ou não, podendo ser compostos por administradores ou empregados das empresas $^{47}$.

\footnotetext{
${ }^{46}$ Sobre o custo de atração de executivos e seu impacto sobre os custos de uma companhia, ver Michael C. Jensen e William H. Meckling, "Theory of the Firm: Managerial Behavior, Agency Costs and Ownership Structure", p. 48-51.

${ }^{47}$ O Formulário de Referência exige a identificação dos participantes em comitês em seu item 12.7, a saber: "Fornecer as informações mencionadas no item 12.6 em relação aos membros dos comitês estatutários, bem como dos comitês de auditoria, de risco, financeiro e de remuneração, ainda que tais comitês ou estruturas não sejam estatutário"
} 
A participação em comitês pode também ser remunerada separadamente, o que impõe a sua divulgação através do Formulário de Referência. Para tanto, as informações sobre a política de remuneração devem abranger comitês de auditoria, de risco, financeiro e de remuneração, bem como estruturas organizacionais assemelhadas, ainda que tais comitês ou estruturas não sejam estatutários, desde que tais comitês ou estruturas participem do processo de decisão dos órgãos de administração ou de gestão do emissor como consultores ou fiscais $^{48}$.

\subsection{Remuneração por participação em reunião de Conselho de Administração}

De acordo com as práticas de governança corporativa adotadas por diferentes empresas, é possível que as reuniões do conselho de administração ocorram em intervalos de alguns meses, sem que os conselheiros tenham contato direto com os diretores da companhia. Para remunerar este trabalho ocasional é comum o pagamento de conselheiros seja definido com base no número de reuniões em que estes participaram.

Esta prática é comum no mercado e, para efeito de divulgação de informações, não foi detalhada dentro do Formulário de Referência. De acordo com a estrutura do documento, as informações de remuneração do conselho de administração são prestadas de forma consolidada.

\subsection{Remuneração através de opções de compra de ações ("stock options")}

O pagamento através de opções de compra de ações, ou "stock options", é realizado através da outorga aos administradores de opções de compra de ações que se tornam exercíveis em determinado momento no futuro a um preço definido.

Cabe ressaltar que a opção de compra de ações não se enquadra no $\S^{\circ}$ do art. 457 da CLT, pois não representa comissão, percentagem, gratificação ajustada, diárias para viagem ou abonos pagos pelo empregador. Não se trata de gratificação pois o administrador paga para obter o direito de compra das ações.

\footnotetext{
${ }^{48}$ Ver nota de rodapé no 23 do Anexo 24 da Instrução CVM no 480/2009.
} 
Tampouco trata-se de prêmio, pois não necessariamente decorre da consecução de objetivos. Como sua valoração ao empregado depende de fatores alheios à companhia que afetam a cotação das ações, também não se caracteriza como participação nos lucros. A natureza jurídica da opção de compra de ações é estritamente mercantil ${ }^{49}$.

Opções de compra são derivativos que garantem a seus detentores o direito de comprar um ativo a um valor definido no presente em uma data futura.

Observa-se que existe pode existir um incentivo considerável para que os administradores se esforcem para conseguir valorizar as ações acima de seu preço de exercício, de forma a maximizar seus ganhos. Entretanto, este mecanismo é de fiscalização mais complexa, visto que a volatilidade das cotações das ações no mercado secundário pode criar dificuldades na aferição dos custos de planos de remuneração baseado em ações.

Adicionalmente, é concebível que um administrador mal intencionado se veja tentado a divulgar informações ao mercado de maneira imprópria próximo da data de exercício de suas opções.

A Instrução CVM n 480/09 determina a divulgação detalhada dos planos de remuneração baseados em ações com o preenchimento dos itens 13.6 até 13.9 do Formulário de Referência. Adicionalmente, cópias dos planos de remuneração baseados em ações devem constar da documentação acessório à assembléia que deliberou sobre eles, conforme determina o art. 13 da Instrução CVM no 481/09 ${ }^{50}$, devendo a companhia incluir as informações do Anexo 13 da referida norma.

\footnotetext{
${ }^{49}$ Nesse sentido ver Sergio Pinto Martins, Direito do Trabalho, $17^{\mathrm{a}}$ edição, São Paulo, Atlas, 2003, p. 231-233.

50 Art. 13 da Instrução CVM nº 481/09: Sempre que a assembléia geral dos acionistas for convocada para aprovar plano de remuneração com base em ações, a companhia deve fornecer, no mínimo, as informações indicadas no Anexo 13 à presente Instrução.
} 


\section{Planos de remuneração baseados em ações}

Resta evidente que um dos elementos de maior complexidade nos planos de remuneração das companhias de capital aberto diz respeito à remuneração baseada em ações ou opções de compra de ações. Neste sentido, a diversidade de formas de estruturação destes planos pode facilitar o seu uso indevido pelos administradores, que, na condição de gestores, podem render-se à tentação de maximizar ganhos pessoais em detrimento de seus deveres fiduciários.

$\mathrm{O}$ tema exige conhecimentos de natureza financeira que ultrapassam o escopo deste trabalho, ainda assim, por seu detalhamento ter sido previsto pela Instrução CVM no 480/2009, é importante trazer à luz alguns conceitos que podem ajudar ao seu melhor entendimento, em particular a definição de opção de compra de ações. Primeiramente é importante conceituarmos alguns termos amplamente utilizados pelo mercado de opções.

Primeiramente, cabe ressaltar que as opções de compra ou venda de ações são instrumentos para administração de risco no mercado financeiro. Neste sentido, o mercado de opções permite que investidores institucionais e de pequeno porte administrem o risco associado a suas carteiras de investimento, aumentando a liquidez ${ }^{51}$ do mercado de ações e, portanto, sua viabilidade como veículo de capitalização das empresas.

Opções de compra de ações são instrumentos financeiros derivativos que permitem a seus proprietários adquirir determinada ação em uma data futura a um valor definido no passado mediante o pagamento antecipado de um prêmio. Assim sendo, é possível estabelecer um valor máximo a ser pago pelo proprietário da opção para que tenha direito a troca da mesma em uma ação determinada, independente a variação da cotação do ativo no mercado. O momento em que o emissor emite a opção é chamado de "outorga", enquanto que o momento em que esta se converte em direito de aquisição do ativo é chamado de "exercício".

O exercício do direito associado a uma opção cabe somente ao seu titular, devendo seu emissor honrar com os valores pactuados anteriormente na data de

\footnotetext{
${ }^{51}$ A liquidez em um mercado é a medida pela circulação e disponibilidade de recursos financeiros, podendo ser entendida, de maneira mais ampla, como a facilidade com a parte interessada em investir encontra a parte que necessita de recursos, ou ainda, como a veclocidade da circulação de moeda na cadeia produtiva.
} 
outorga. Com isso, caso a cotação em bolsa da ação a que a opção de refere esteja acima do preço definido anteriormente, chamado "preço de exercício", o exercício da opção irá beneficiar o titular. Por outro lado, caso a cotação de mercado da ação estiver abaixo do preço de exercício da opção, será mais benéfico ao titular não exercer o direito de conversão. Neste caso, a opção de compra se encerra e sem que seja exercida, ou, no jargão do mercado, nesta hipótese a opção "virou pó”.

O mercado utiliza o termo "in the money" para opções cujo valor de face esteja abaixo da cotação de mercado na data de exercício, estas opções geram ganhos aos seus proprietários. O termo "out of the money" é utilizado para as opções que possuem valor de face abaixo da cotação de mercado, nestes casos os ganhos ficam com seus emissores, que, no mercado financeiro, embolsam os prêmios associados a emissão das opções. O Anexo III do presente trabalho apresenta em um gráfico exemplificando as situações descritas nos parágrafos anteriores.

Algumas distinções devem ser feitas quando falamos de opções no mercado financeiro ou como remuneração da administração, em particular no que tange o seu momento de exercício e outorga. No mercado financeiro, o exercício da opção ocorre com o pagamento da diferença entre o preço de exercício e o valor da cotação no mercado, sem que ocorra a efetiva entrega da ação ao titular da opção. Por outro lado, na maioria dos casos os planos remuneração com opções de compra de ações são feitos com a efetiva entrega do ativo aos administradores, o que pode levar a companhia emitir ações ou adquirir as mesmas no mercado.

Por outro lado, em determinados planos de remuneração através de opções de compra, os administradores são remunerados com os valores a que teriam direito caso tivessem recebido os ativos relacionados, sem que efetivamente tenha havido a emissão ou aquisição de ações em mercado pela companhia. Estes planos apresentam vantagens evidentes para a companhia, tanto do ponto de vista regulatório quanto pela sua facilidade de administração, e, apesar de menos comuns no mercado brasileiro, são amplamente utilizados por empresas americanas. Os planos de remuneração baseado em ações que não exigem a troca 
dos referidos ativos são referidos na doutrina americana como planos de "phantom shares".

Diversos termos são utilizados para categorizar diferentes tipos de planos de remuneração baseado em ações, e não é objetivo deste trabalho detalhar cada um deles. Ademais, a doutrina especializada e a criatividade dos administradores criam continuamente variações para as formas de remuneração utilizando ações, aumentando continuamente a complexidade da categorização. Resta saber que, independentemente do tipos de plano de remuneração baseado em ações, é sempre possível determinar seu custo para a companhia.

\subsection{Custo da remuneração por opções para as companhias}

Tendo em vista o que foi dito anteriormente e a variação continua da cotação das ações em bolsa de valores poderia parecer que a determinação dos custos para a companhia de um plano de remuneração baseado em ações não seria mensurável previamente. Entretanto, utilizando as devidas ferramentas financeiras, todo qualquer plano de opções pode ter seu custo determinado de forma definitiva através de modelos de análise conhecidos no mercado como "Black and Scholes" ou através do modelo "Binomial".

A matemática envolvida no desenvolvimento dos referidos modelos de precificação de opções não é algo elementar, sendo mais produtivo determinar quais são as variáveis que devem ser definidas pela administração de forma a tornar o custo de seus planos de opções conhecidos e determinados. Assim sendo, os seguintes elementos devem ser definidos de forma a tornar conhecidos os custos de um plano de remuneração através de opções de compra de ações: (i) o preço da ação no mercado; (ii) o preço de exercício da opção; (iii) a taxa de juros livre de risco anualizada, capitalizada continuamente; (iv) a volatilidade da ação, isto é, a variação em determinado período; e (v) o período de tempo até o exercício. Nota-se que todos os elementos que possibilitam a precificação de um plano de opções são de conhecimento da companhia no momento da elaboração do plano. 


\section{Conclusão}

Conforme foi fundamentado anteriormente, a definição clara das políticas e práticas de remuneração das companhias abertas é mais importante para a consecução dos objetivos dos proprietários, superando em eficácia o mero incremento dos valores recebidos ${ }^{52}$. Assim sendo, o detalhamento das informações imposta pelos reguladores dos mercados de capitais no Brasil e no atenta para uma necessidade identificada pela doutrina especializada. As entidades preocupadas com a governança corporativa das empresas brasileiras de capital aberto também reconheceram esta necessidade, impondo a seus membros a determinação de divulgar, ainda que de maneira consolidada, os montantes pagos aos diretores e conselheiros.

As inovações trazidas pela Instrução CVM no 480/2009, que instituiu em seu art. 24 o Formulário de Referência, impõem a divulgação das informações sobre a remuneração da administração de maneira categorizada, distinguindo seus diferentes elementos constitutivos. Ainda assim, a forma de divulgação consolidada por órgão societário ou exercício adotada pela CVM impede a identificação individual dos titulares dos valores pagos.

\footnotetext{
${ }^{52}$ Para o impacto de modelos de remuneração no comportamento dos administradores ver Jensen e Murphy, "CEO Incentives - It's not how much you pay, but how", Harvard Business Review, No. 3, 1990, p. 138-153.
} 


\section{Anexo I - Remuneração dos administradores por órgão societário.}

Com base nas informações apresentadas até novembro de 2010 pelas companhias que compõem o índice Bovespa, através do Sistema de Informações Periódicas eventuais da Comissão de Valores Mobiliários, é possível saber detalhes a respeito das espécies de remuneração mais comuns no mercado brasileiro e sua distribuição dentro da sociedade. A seguir serão apresentadas algumas interpretações possíveis e conclusões fundamentadas nos valores remuneração apresentados por estas companhias.

\subsection{Remuneração dos administradores por órgão societário}

É possível afirmar que existe a remuneração total anual atribuída à diretoria estatutária é significativamente maior que aquela conferida ao conselho de administração e fiscal. O gráfico abaixo relaciona a evolução da remuneração nos exercícios sociais de 2007 até 2010 para cada órgão societário.

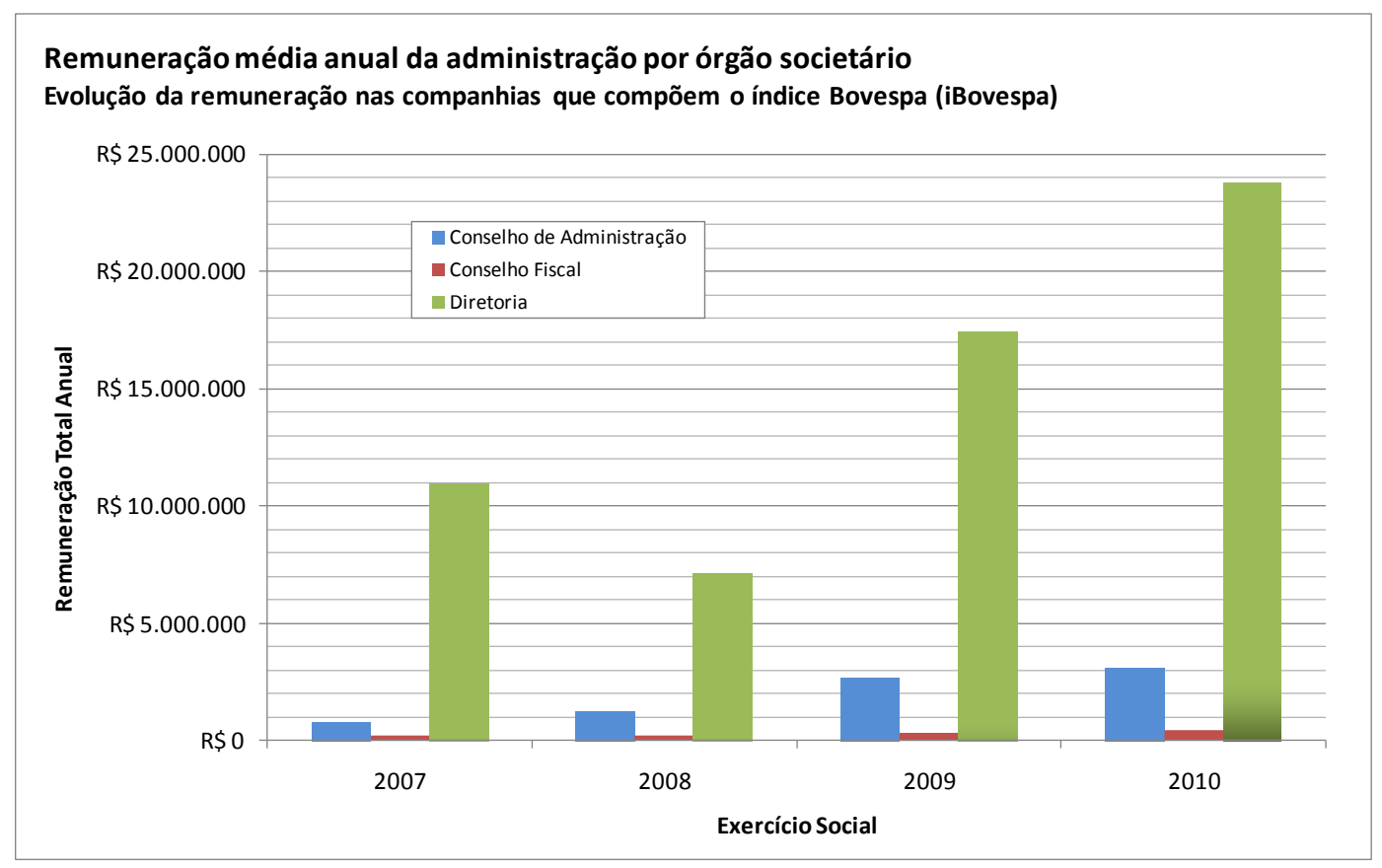

Conclui-se pelo gráfico acima que as remunerações pagas a diretores podem ser muito maiores que aquelas a que fazem direito os conselheiros, tendo em vista a diferença significativa que as empresas remuneram seu pessoal estratégico nestas condições. Os valores que compõem o gráfico acima foram divulgados através do Formulário de Referência, em seu item 13.2, letra "e". Os 
montantes relativos ao exercício de 2010 dizem respeito às projeções feitas pelas companhias quando da apresentação da referida documentação.

\begin{tabular}{|c|c|c|c|}
\multicolumn{4}{|c}{ Valores médios da remuneração anual por órgão societário } \\
\hline \multirow{2}{*}{ Exercício Social } & $\begin{array}{c}\text { Conselho de } \\
\text { Administração }\end{array}$ & Conselho Fiscal & Diretoria \\
\hline 2007 & $810.159,54$ & $207.891,86$ & $10.978 .734,70$ \\
2008 & $1.230 .518,22$ & $234.113,89$ & $7.156 .158,28$ \\
2009 & $2.672 .862,51$ & $326.658,05$ & $17.398 .394,42$ \\
2010 & $3.052 .586,54$ & $420.879,76$ & $23.764 .933,12$ \\
\hline Total geral & $2.420 .242,87$ & $335.978,96$ & $17.608 .851,34$ \\
\hline
\end{tabular}

\subsection{Distribuição dos elementos de remuneração da diretoria estatutária}

Como foi mencionado anteriormente, a forma como a remuneração é estruturada é essencial para o alinhamento entre a administração e os acionistas. O gráfico abaixo apresenta a distribuição média dos elementos de remuneração para a diretoria estatutária divulgado pelas companhias que compõem o índice Bovespa para o exercício social de 2010.

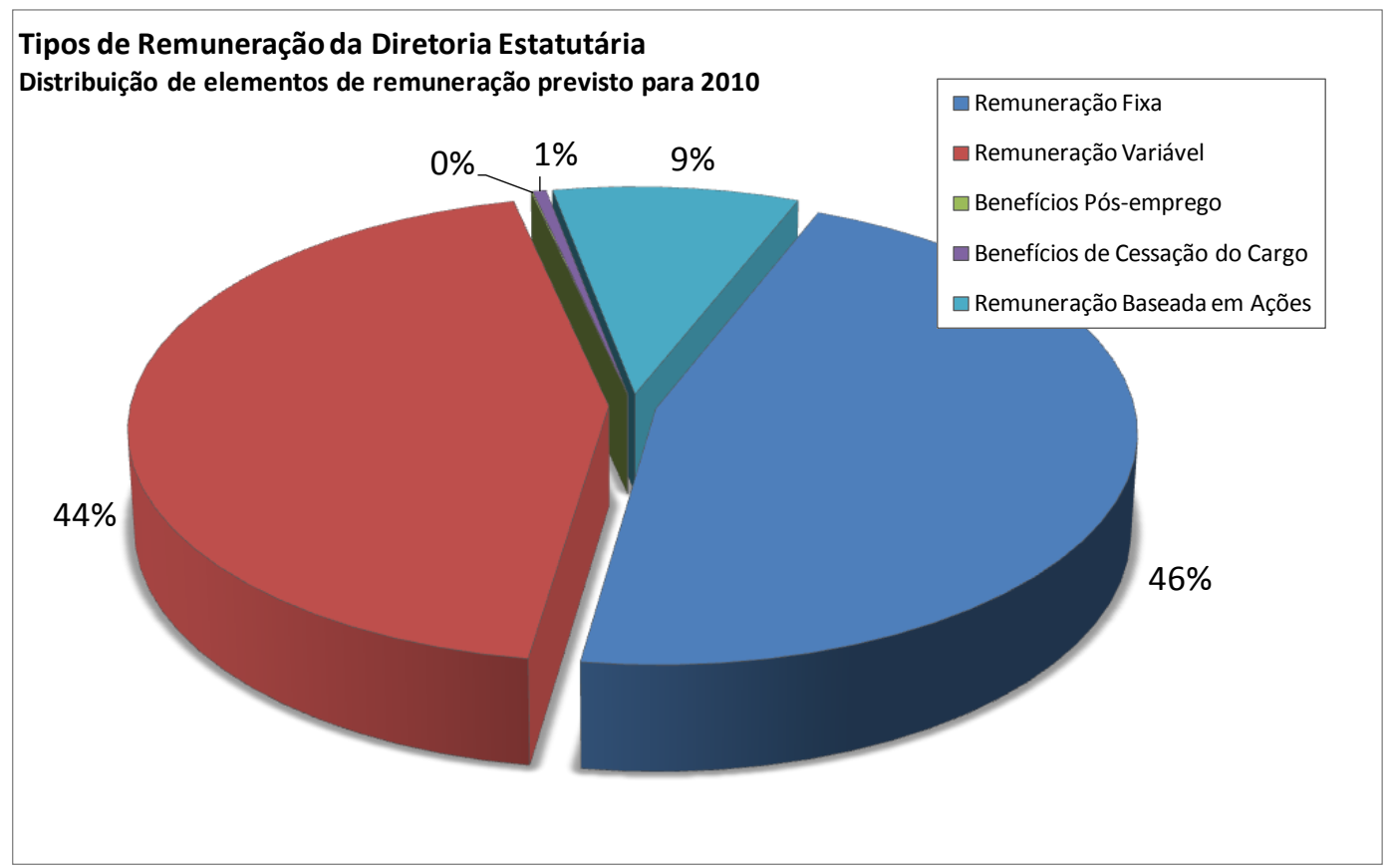

Os valores para a remuneração baseada em ações são mensurados com base nos processos referidos previamente neste trabalho, ou seja, o montantes dos planos de remuneração baseado em ações são aferidos pelas companhias através 
de ferramentas financeiras como a equação de Black e Scholes ou o modelo Binomial.

A distribuição média dos elementos que compõem a remuneração conselho fiscal é apresentada abaixo. Observa-se a inexistência de remuneração variável para estes órgãos societários em todas as companhias do índice Bovespa.

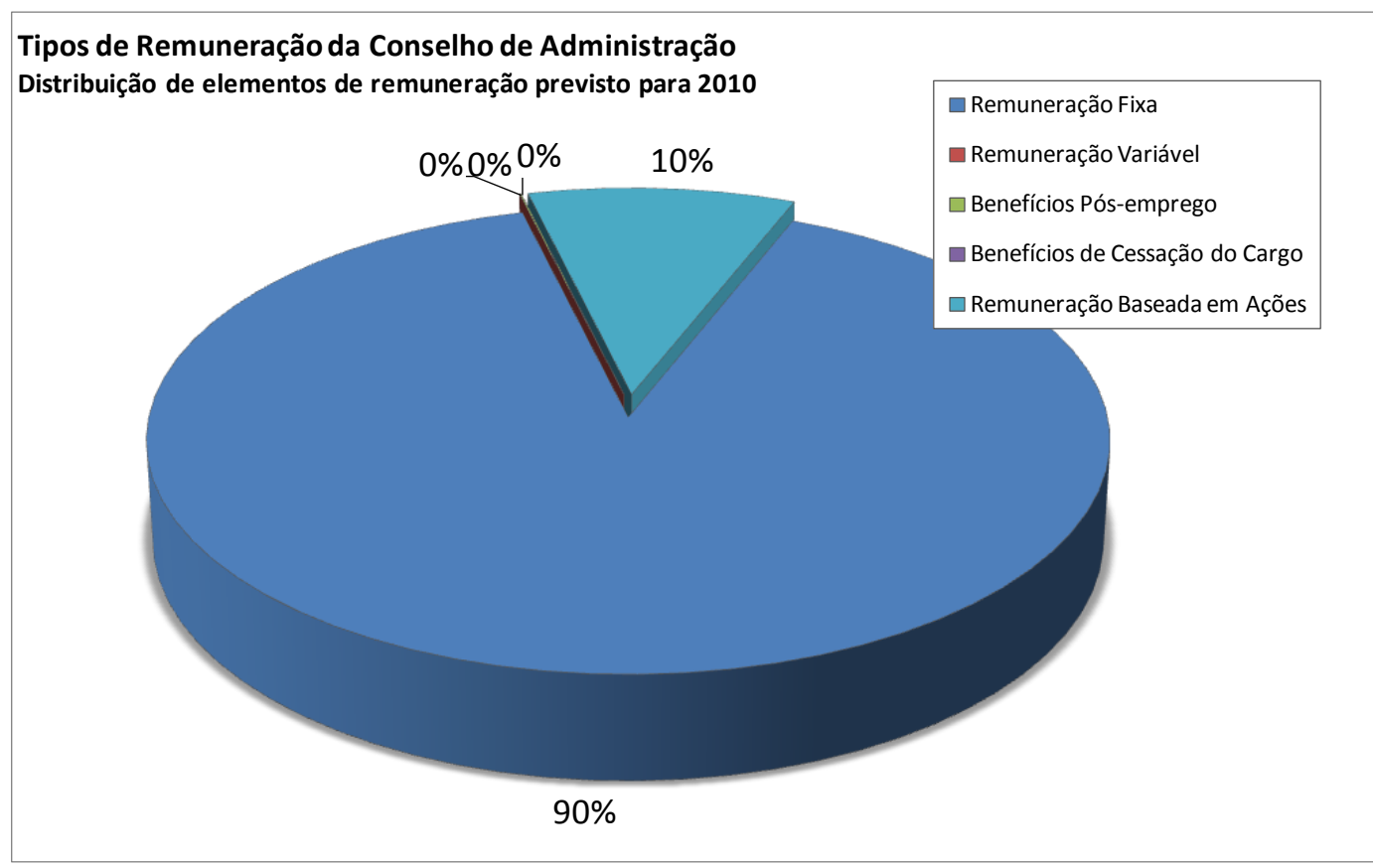

Podemos dizer que o a ausência de remuneração variável para os membros do conselho de administração está em linha com as melhores práticas definidas para a governança corporativa ${ }^{53}$. O mesmo cuidado pode ser visto na distribuição dos elementos de remuneração dos conselhos fiscais, onde existe somente a parcela de remuneração fixa para todas as companhias analisadas ${ }^{54}$.

\footnotetext{
53 "Os conselheiros devem ser adequadamente remunerados, considerando o mercado, as qualificações, o valor gerado à organização e os riscos da atividade. Contudo, as estruturas de incentivo da remuneração do Conselho devem ser diferentes daquelas empregadas para a gestão, dada a natureza distinta destas duas instâncias da organização. A remuneração baseada em resultados de curto prazo deve ser evitada para o Conselho." e "O acesso do conselheiro a uma eventual parcela da remuneração em ações ou nelas referenciada só deve ser permitido em prazo superior ao definido para os gestores." (IBGC, 2009, p. 40-41)

54 "Não deve haver remuneração variável para Conselho Fiscal. O montante deve ser fixado em função da remuneração total atribuída aos executivos, incluindo valores recebidos por estes através de diferentes empresas de um mesmo grupo.” (IBGC, 2009, p. 65)
} 


\subsection{Lista das companhias que compõem o índice Bovespa}

O Índice Bovespa, ou Ibovespa ${ }^{55}$, é o mais importante indicador do desempenho médio das cotações do mercado de ações brasileiro. Sua relevância advém do fato do Ibovespa retratar o comportamento dos principais papéis negociados na principal bolsa do Brasil desde 1968. A tabela abaixo ${ }^{56}$ mostra as companhias que atualmente compõem o Ibovespa e que serviram de base para os dados apresentados para remuneração de companhias abertas nos gráficos apresentados anteriormente.

\begin{tabular}{|c|c|c|c|c|c|}
\hline Código & Companhia & Tipo de Ação & Segmento & Qtde. Teórica & Part. (\%) \\
\hline ALLL3 & ALL AMER LAT & ON EG NM & Novo Mercado & 48,57809681 & 1,104 \\
\hline AMBV4 & AMBEV & $\mathrm{PN}$ & & 2,903859711 & 0,979 \\
\hline BBAS3 & BRASIL & ON NM & Novo Mercado & 56,46155139 & 2,726 \\
\hline BBDC4 & BRADESCO & PN N1 & Nível 1 & 60,86524071 & 3,13 \\
\hline BISA3 & BROOKFIELD & ON NM & Novo Mercado & 48,33794669 & 0,622 \\
\hline BRAP4 & BRADESPAR & PN N1 & Nível 1 & 16,20426475 & 0,993 \\
\hline BRFS3 & BRF FOODS & ON NM & Novo Mercado & 39,00701223 & 1,341 \\
\hline BRKM5 & BRASKEM & PNA N1 & Nível 1 & 23,89977415 & 0,596 \\
\hline BRTO4 & BRASIL TELEC & PN & & 22,2724676 & 0,39 \\
\hline BTOW3 & B2W VAREJO & ON NM & Novo Mercado & 16,58125506 & 0,701 \\
\hline BVMF3 & BMFBOVESPA & ON NM & Novo Mercado & 196,0269302 & 3,902 \\
\hline CCRO3 & CCR RODOVIAS & ON NM & Novo Mercado & 12,7347319 & 0,802 \\
\hline CESP6 & CESP & PNB N1 & Nível 1 & 17,38535388 & 0,685 \\
\hline CIEL3 & CIELO & ON NM & Novo Mercado & 75,66436451 & 1,539 \\
\hline CMIG4 & CEMIG & PN N1 & Nível 1 & 27,47012284 & 1,134 \\
\hline CPFE3 & CPFL ENERGIA & ON NM & Novo Mercado & 7,657248354 & 0,441 \\
\hline CPLE6 & COPEL & PNB N1 & Nível 1 & 10,57356334 & 0,598 \\
\hline CRUZ3 & SOUZA CRUZ & ON & & 3,531960306 & 0,443 \\
\hline CSAN3 & COSAN & ON NM & Novo Mercado & 20,88130377 & 0,784 \\
\hline CSNA3 & SID NACIONAL & $\mathrm{ON}$ & & 57,79927459 & 2,359 \\
\hline CYRE3 & CYRELA REALT & ON NM & Novo Mercado & 57,40435365 & 1,866 \\
\hline DTEX3 & DURATEX & ON NM & Novo Mercado & 21,75101451 & 0,589 \\
\hline ECOD3 & ECODIESEL & ON NM & Novo Mercado & 729,1401429 & 1,311 \\
\hline ELET3 & ELETROBRAS & ON N1 & Nível 1 & 26,34730316 & 0,89 \\
\hline ELET6 & ELETROBRAS & PNB N1 & Nível 1 & 18,53720611 & 0,743 \\
\hline ELPL6 & ELETROPAULO & PNB N2 & Nível 2 & 12,57704075 & 0,53 \\
\hline EMBR3 & EMBRAER & ON NM & Novo Mercado & 44,13255018 & 0,755 \\
\hline FIBR3 & FIBRIA & ON NM & Novo Mercado & 36,9007164 & 1,498 \\
\hline GFSA3 & GAFISA & ON NM & Novo Mercado & 84,89737247 & 1,648 \\
\hline GGBR4 & GERDAU & PN N1 & Nível 1 & 86,84037557 & 2,574 \\
\hline GOAU4 & GERDAU MET & PN N1 & Nível 1 & 18,59002098 & 0,66 \\
\hline GOLL4 & GOL & PN N2 & Nível 2 & 28,68913463 & 1,211 \\
\hline ITSA4 & ITAUSA & PN N1 & Nível 1 & 118,7143361 & 2,315 \\
\hline ITUB4 & ITAUUNIBANCO & PN N1 & Nível 1 & 65,85626538 & 4,015 \\
\hline JBSS3 & JBS & ON NM & Novo Mercado & 100,8876674 & 0,934 \\
\hline KLBN4 & KLABIN S/A & PN N1 & Nível 1 & 59,71802676 & 0,404 \\
\hline LAME4 & LOJAS AMERIC & PN I10 & & 49,23728775 & 1,207 \\
\hline LIGT3 & LIGHT S/A & ON NM & Novo Mercado & 17,53249991 & 0,541 \\
\hline LLXL3 & LLX LOG & ON NM & Novo Mercado & 69,08340566 & 0,914 \\
\hline LREN3 & LOJAS RENNER & ON NM & Novo Mercado & 11,85810999 & 1,098 \\
\hline MMXM3 & MMX MINER & ON NM & Novo Mercado & 73,98056458 & 1,44 \\
\hline MRFG3 & MARFRIG & ON NM & Novo Mercado & 25,24141597 & 0,546 \\
\hline MRVE3 & MRV & ON NM & Novo Mercado & 51,6410948 & 1,233 \\
\hline NATU3 & NATURA & ON NM & Novo Mercado & 12,46152661 & 0,845 \\
\hline OGXP3 & OGX PETROLEO & ON NM & Novo Mercado & 117,9064582 & 3,773 \\
\hline
\end{tabular}

55 Para mais detalhes sobre a composição e histórico do Ibovespa ver [http://www.bmfbovespa.com.br/indices/ResumoIndice.aspx? Indice=Ibovespa].

56 A composição do Ibovespa apresentada na tabela foi retirada do site da BM\&FBovespa em 21.10.2010. 


\begin{tabular}{|c|c|c|c|c|c|}
\hline Código & Companhia & Tipo de Ação & Segmento & Qtde. Teórica & Part. (\%) \\
\hline PCAR5 & P.ACUCAR-CBD & PNA N1 & Nível 1 & 9,138564027 & 0,808 \\
\hline PDGR3 & PDG REALT & ON NM & Novo Mercado & 90,44912641 & 2,745 \\
\hline PETR3 & PETROBRAS & $\mathrm{ON}$ & & 57,34338685 & 2,206 \\
\hline PETR4 & PETROBRAS & PN & & 244,6015403 & 8,517 \\
\hline RDCD3 & REDECARD & ON NM & Novo Mercado & 38,61181706 & 1,283 \\
\hline RSID3 & ROSSI RESID & ON NM & Novo Mercado & 49,38271609 & 1,163 \\
\hline SANB11 & SANTANDER BR & UNT N2 & Nível 2 & 31,4769323 & 1,097 \\
\hline SBSP3 & SABESP & ON NM & Novo Mercado & 6,437681408 & 0,352 \\
\hline TAMM4 & TAM S/A & PN N2 & Nível 2 & 17,99374529 & 1,041 \\
\hline TCSL3 & TIM PART S/A & $\mathrm{ON}$ & & 12,88115388 & 0,125 \\
\hline TCSL4 & TIM PART S/A & PN & & 111,6614063 & 0,84 \\
\hline TLPP4 & TELESP & PN & & 2,681030679 & 0,155 \\
\hline TMAR5 & TELEMAR N L & PNA & & 3,27370875 & 0,225 \\
\hline TNLP3 & TELEMAR & $\mathrm{ON}$ & & 5,570923935 & 0,268 \\
\hline TNLP4 & TELEMAR & PN & & 24,88646582 & 0,923 \\
\hline TRPL4 & TRAN PAULIST & PN N1 & Nível 1 & 3,033960969 & 0,229 \\
\hline UGPA4 & ULTRAPAR & PN N1 & Nível 1 & 3,226906895 & 0,486 \\
\hline USIM3 & USIMINAS & ON N1 & Nível 1 & 17,00004341 & 0,592 \\
\hline USIM5 & USIMINAS & PNA N1 & Nível 1 & 83,1244939 & 2,462 \\
\hline VALE3 & VALE & ON EJ N1 & Nível 1 & 37,70053892 & 2,925 \\
\hline VALE5 & VALE & PNA EJ N1 & Nível 1 & 172,3211787 & 11,956 \\
\hline VIVO4 & VIVO & PN & & 11,43883513 & 0,793 \\
\hline Quantidade Teórica Total & & & & $3.739,00$ & 100 \\
\hline
\end{tabular}

A composição da carteira do Ibovespa procura se aproximar da configuração real das negociações que ocorrem na BM\&FBovespa. Atualmente, 61 companhias abertas possuem ações na carteira teórica do índice, com algumas apresentando mais de uma classe ou espécie na composição ${ }^{57}$.

\footnotetext{
${ }^{57}$ Como se pode ver na tabela do lbovespa, algumas empresas possuem ações preferenciais e
} ordinárias na composição do índice, como Petrobrás, Vale S.A. e Usiminas, por exemplo. 


\section{Anexo II - Divulgação da remuneração dos administradores (Seção 13 do Formulário de Referência).}

As informações sobre a remuneração da administração adquiriram um nível de detalhamento elevado no Formulário de Referência, previsto pelo art. 24 da Instrução CVM n 480/09 e definido pelo Anexo 24 da referida norma. Abaixo segue a tabela com todos os itens sobre remuneração que devem ser divulgados pelas companhias abertas no país ${ }^{58}$ :

\section{Remuneração dos administradores}

13.1. Descrever a política ou prática de remuneração do conselho de administração, da diretoria estatutária e não estatutária, do conselho fiscal, dos comitês estatutários e dos comitês de auditoria, de risco, financeiro e de remuneração, abordando os seguintes aspectos:

a. objetivos da política ou prática de remuneração

b. composição da remuneração, indicando:

i. descrição dos elementos da remuneração e os objetivos de cada um deles

ii. qual a proporção de cada elemento na remuneração total

iii. metodologia de cálculo e de reajuste de cada um dos elementos da remuneração

iv. razões que justificam a composição da remuneração

c. principais indicadores de desempenho que são levados em consideração na determinação de cada elemento da remuneração

d. como a remuneração é estruturada para refletir a evolução dos indicadores de desempenho

e. como a política ou prática de remuneração se alinha aos interesses do emissor de curto, médio e longo prazo

f. existência de remuneração suportada por subsidiárias, controladas ou controladores diretos ou indiretos

g. existência de qualquer remuneração ou benefício vinculado à ocorrência de determinado evento societário, tal como a alienação do controle societário do emissor

13.2. Em relação à remuneração reconhecida no resultado dos 3 últimos exercícios sociais e à prevista para o exercício social corrente do conselho de administração, da diretoria estatutária e do conselho fiscal, elaborar tabela com o seguinte conteúdo:

\begin{tabular}{|l|}
\hline a. órgão \\
\hline b. número de membros \\
\hline c. remuneração segregada em: \\
\hline i. remuneração fixa anual, segregada em: \\
\hline • salário ou pró-labore \\
\hline • benefícios diretos e indiretos \\
\hline • remuneração por participação em comitês \\
\hline • outros \\
\hline ii. remuneração variável, segregada em: \\
\hline • bônus \\
\hline • participação nos resultados \\
\hline •remuneração por participação em reuniões \\
\hline • comissões \\
\hline iii. benefícios pós-emprego \\
\hline iv. benefícios motivados pela cessação do exercício do cargo \\
\hline v. remuneração baseada em ações \\
\hline
\end{tabular}

${ }^{58}$ Companhias abertas classificadas como categoria B estão obrigadas a divulgar apenas os itens 13.2 e 13.13, sendo facultativa a informação prestada nos demais itens desta seção. Companhias categoria B estão definidas no art. $2^{\circ}$, $\$ 2^{\circ}$ da Instrução CVM n ${ }^{\circ} 480 / 09$ e caracterizam-se pela proibição em negociar ações e certificados de depósito de ações, seja diretamente ou através de outros valores mobiliários. 
d. valor, por órgão, da remuneração do conselho de administração, da diretoria estatutária e do conselho fiscal

e. total da remuneração do conselho de administração, da diretoria estatutária e do conselho fiscal

13.3. Em relação à remuneração variável dos 3 últimos exercícios sociais e à prevista para o exercício social corrente do conselho de administração, da diretoria estatutária e do conselho fiscal, elaborar tabela com o seguinte conteúdo:

a.órgão

b. número de membros em relação ao bônus:

i. valor mínimo previsto no plano de remuneração

ii. valor máximo previsto no plano de remuneração

iii. valor previsto no plano de remuneração, caso as metas estabelecidas fossem atingidas

iv. valor efetivamente reconhecido no resultado dos 3 últimos exercícios sociais

d. em relação à participação no resultado:

i. valor mínimo previsto no plano de remuneração

ii. valor máximo previsto no plano de remuneração

iii. valor previsto no plano de remuneração, caso as metas estabelecidas fossem atingidas

iv. valor efetivamente reconhecido no resultado dos 3 últimos exercícios sociais

13.4. Em relação ao plano de remuneração baseado em ações do conselho de administração e da diretoria estatutária, em vigor no último exercício social e previsto para o exercício social corrente, descrever:

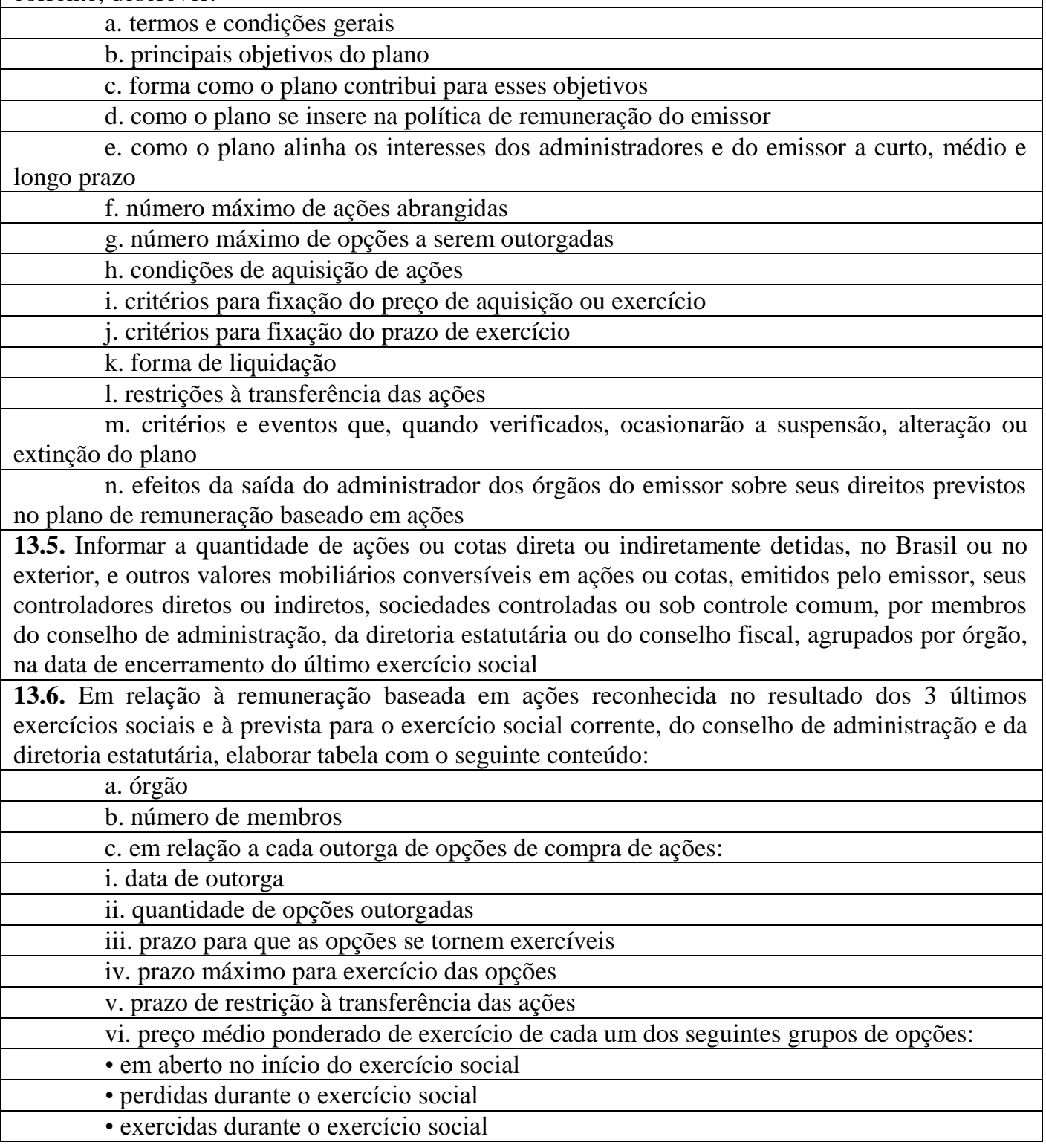


- expiradas durante o exercício social

d. valor justo das opções na data de outorga

e. diluição potencial em caso de exercício de todas as opções outorgadas

13.7. Em relação às opções em aberto do conselho de administração e da diretoria estatutária ao final do último exercício social, elaborar tabela com o seguinte conteúdo:

\begin{tabular}{|l|}
\hline a.órgão \\
\hline b. número de membros \\
\hline c. em relação às opções ainda não exercíveis \\
\hline i. quantidade \\
\hline ii. data em que se tornarão exercíveis \\
\hline iii. prazo máximo para exercício das opções \\
\hline iv. prazo de restrição à transferência das ações \\
\hline v. preço médio ponderado de exercício \\
\hline vi. valor justo das opções no último dia do exercício social \\
\hline d. em relação às opções exercíveis \\
\hline i. quantidade \\
\hline ii. prazo máximo para exercício das opções \\
\hline iii. prazo de restrição à transferência das ações \\
\hline iv. preço médio ponderado de exercício \\
\hline v. valor justo das opções no último dia do exercício social \\
\hline vi. valor justo do total das opções no último dia do exercício social \\
\hline 13.8. Em relação às opções exercidas e ações entregues relativas à remuneração baseada em ações \\
do conselho de administração e da diretoria estatutária, nos 3 últimos exercícios sociais, elaborar \\
tabela com o seguinte conteúdo: \\
\hline a.órgão \\
\hline b. número de membros \\
\hline c. em relação às opções exercidas informar: \\
\hline i. número de ações \\
\hline ii. preço médio ponderado de exercício \\
\hline iii. valor total da diferença entre o valor de exercício e o valor de mercado das ações \\
\hline ii. preço médio ponderado de aquisição \\
\hline relativas às opções exercidas \\
\hline i. em relação às ações entregues informar: \\
\hline \\
\hline iiridas da diferença entre o valor de aquisição e o valor de mercado das ações \\
\hline
\end{tabular}

13.9. Descrição sumária das informações necessárias para a compreensão dos dados divulgados nos itens 13.6 a 13.8, tal como a explicação do método de precificação do valor das ações e das opções, indicando, no mínimo:

a. modelo de precificação

b. dados e premissas utilizadas no modelo de precificação, incluindo o preço médio ponderado das ações, preço de exercício, volatilidade esperada, prazo de vida da opção, dividendos esperados e a taxa de juros livre de risco

c. método utilizado e as premissas assumidas para incorporar os efeitos esperados de exercício antecipado

d. forma de determinação da volatilidade esperada justo

e. se alguma outra característica da opção foi incorporada na mensuração de seu valor

13.10. Em relação aos planos de previdência em vigor conferidos aos membros do conselho de administração e aos diretores estatutários, fornecer as seguintes informações em forma de tabela: a.órgão

b. número de membros

c. nome do plano

d. quantidade de administradores que reúnem as condições para se aposentar

e. condições para se aposentar antecipadamente

f. valor atualizado das contribuições acumuladas no plano de previdência até o encerramento do último exercício social, descontada a parcela relativa

a contribuições feitas diretamente pelos administradores 
g. valor total acumulado das contribuições realizadas durante o último exercício social, descontada a parcela relativa a contribuições feitas diretamente pelos administradores

h. se há a possibilidade de resgate antecipado e quais as condições

13.11. Em forma de tabela, indicar, para os 3 últimos exercícios sociais, em relação ao conselho de administração, à diretoria estatutária e ao conselho fiscal:

\begin{tabular}{|l|}
\hline a.órgão \\
\hline b. número de membros \\
\hline c. valor da maior remuneração individual \\
\hline d. valor da menor remuneração individual \\
\hline e. valor médio de remuneração individual \\
\hline
\end{tabular}

13.12. Descrever arranjos contratuais, apólices de seguros ou outros instrumentos que estruturem mecanismos de remuneração ou indenização para os administradores em caso de destituição do cargo ou de aposentadoria, indicando quais as consequências financeiras para o emissor

13.13. Em relação aos 3 últimos exercícios sociais, indicar o percentual da remuneração total de cada órgão reconhecida no resultado do emissor referente a membros do conselho de administração, da diretoria estatutária ou do conselho fiscal que sejam partes relacionadas aos controladores, diretos ou indiretos, conforme definido pelas regras contábeis que tratam desse assunto

13.14. Em relação aos 3 últimos exercícios sociais, indicar os valores reconhecidos no resultado do emissor como remuneração de membros do conselho de administração, da diretoria estatutária ou do conselho físcal, agrupados por órgão, por qualquer razão que não a função que ocupam, como por exemplo, comissões e serviços de consultoria ou assessoria prestados

13.15. Em relação aos 3 últimos exercícios sociais, indicar os valores reconhecidos no resultado de controladores, diretos ou indiretos, de sociedades sob controle comum e de controladas do emissor, como remuneração de membros do conselho de administração, da diretoria estatutária ou do conselho fiscal do emissor, agrupados por órgão, especificando a que título tais valores foram atribuídos a tais indivíduos

13.16. Fornecer outras informações que o emissor julgue relevantes 


\section{Anexo III - Relação entre valores em opções: preço de exercício e preço de outorga.}

O gráfico abaixo representa uma situação hipotética que ilustra alguns conceitos essenciais à compreensão do funcionamento de opções de compra de ações, em particular a relação que a cotação possui com o preço de exercício e de outorga nas referidas datas.

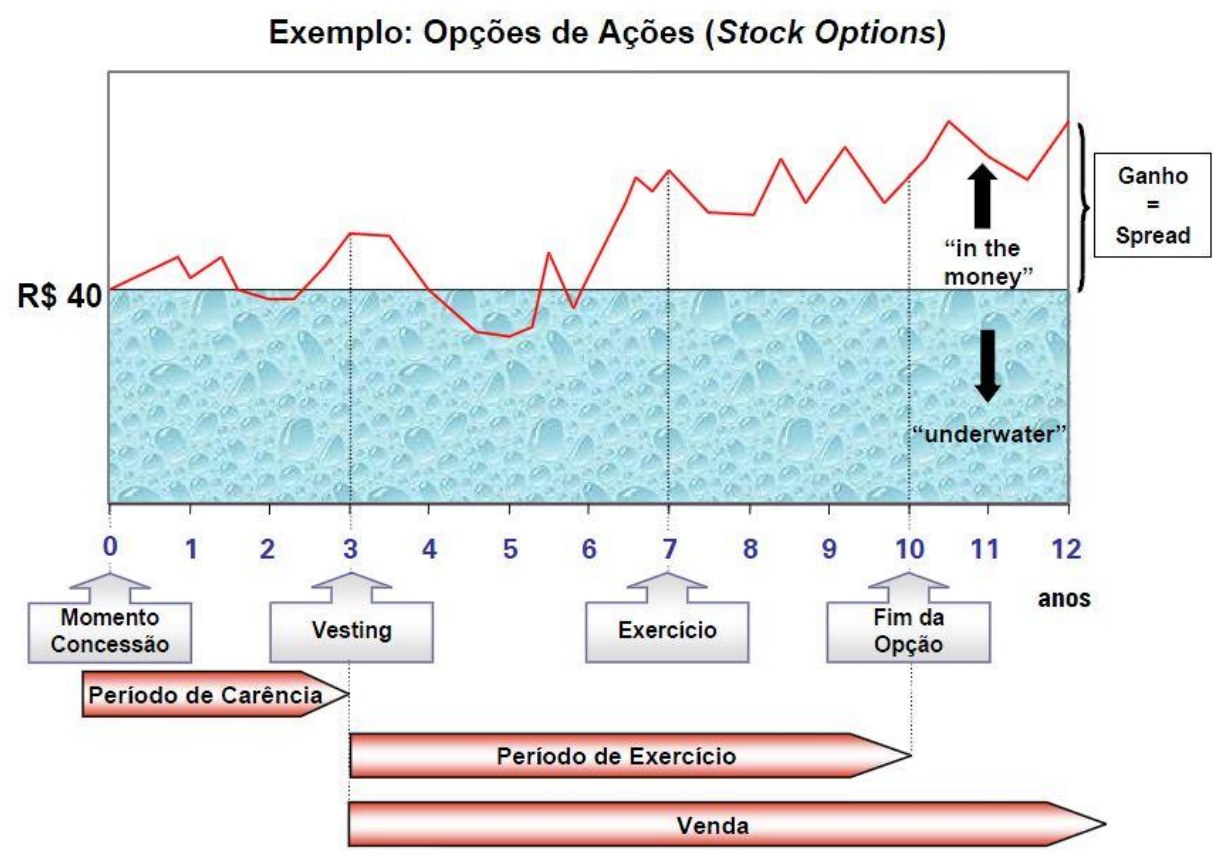

Glossário de termos utilizados no gráfico:

- "in the money": cotação em mercado superior ao preço de exercício.

- "underwater" ou "out of the money": cotação de mercado inferior ao preço de exercício.

- "vesting": momento em que a opção se torna exercível.

- Fim da opção: limite de tempo em que a opção pode ser exercida, pode ser entendida como a validade da opção.

- Período de carência: lapso temporal entre a concessão, ou outorga, da opção e o momento em que ela se torna exercível para seu titular.

- Período de exercício: lapso temporal entre o momento em que a opção se torna exercível e o término da validade da opção, com seu encerramento sem exercício.

- Venda: período em que o titular da opção pode fazer a sua alienação para terceiros, desde que seja admissível no plano de remuneração em questão. 


\section{Anexo IV - Remuneração divulgada pelas companhias do lbovespa para os exercícios de 2009 e} 2010.

\begin{tabular}{|c|c|c|c|c|c|c|c|c|}
\hline \multirow[b]{2}{*}{ Razão Social da Companhia Aberta } & \multicolumn{3}{|c|}{2009} & \multirow{2}{*}{$\begin{array}{c}\text { Total para } \\
2009\end{array}$} & \multicolumn{3}{|c|}{2010} & \multirow{2}{*}{$\begin{array}{c}\text { Total para } \\
2010\end{array}$} \\
\hline & $\begin{array}{c}\text { Conselho de } \\
\text { Administração }\end{array}$ & $\begin{array}{c}\text { Conselho } \\
\text { Fiscal }\end{array}$ & Diretoria & & $\begin{array}{c}\text { Conselho de } \\
\text { Administração }\end{array}$ & $\begin{array}{c}\text { Conselho } \\
\text { Fiscal }\end{array}$ & Diretoria & \\
\hline ALL - AMÉRICA LATINA LOGISTICA S.A. & $14.095 .000,00$ & $375.000,00$ & $6.365 .000,00$ & $20.835 .000,00$ & $28.278 .000,00$ & $518.000,00$ & $7.342 .000,00$ & $108.414 .000,00$ \\
\hline B2W - COMPANHIA GLOBAL DO VAREJO & $8.231 .211,00$ & & $351.763,00$ & $8.582 .974,00$ & $13.427 .211,00$ & $144.000,00$ & $586.896,00$ & $42.474 .321,00$ \\
\hline BANCO BRADESCO SA & $92.779 .000,00$ & $432.000,00$ & $18.520 .000,00$ & $111.731 .000,00$ & $138.000 .000,00$ & $432.000,00$ & $32.000 .000,00$ & $511.296 .000,00$ \\
\hline BANCO DO BRASIL S.A. & $25.378 .134,38$ & $197.233,89$ & $236.680,67$ & $25.812 .048,94$ & $8.827 .485,24$ & $50.562,00$ & $60.674,40$ & $26.816 .164,92$ \\
\hline BANCO SANTANDER (BRASIL) S.A. & $168.508 .484,00$ & & - & $168.508 .484,00$ & $242.420 .000,00$ & & $4.140 .000,00$ & $493.120 .000,00$ \\
\hline $\begin{array}{l}\text { BMFBOVESPA S.A. BOLSA VALORES MERC } \\
\text { FUT }\end{array}$ & $17.826 .056,78$ & & $3.702 .348,37$ & $21.528 .405,15$ & $14.384 .692,14$ & & $4.074 .538,92$ & $36.918 .462,12$ \\
\hline BRADESPAR S/A & $2.616 .000,00$ & $87.600,00$ & - & $2.703 .600,00$ & $4.500 .000,00$ & $262.800,00$ & $120.000,00$ & $14.648 .400,00$ \\
\hline $\begin{array}{l}\text { BRASIL ECODIESEL IND. E COM. DE } \\
\text { BIOCOMB. E ÓLEOS VEGETAIS S/A }\end{array}$ & $3.062 .916,66$ & $216.000,00$ & $462.000,00$ & $3.740 .916,66$ & $3.556 .000,00$ & $216.000,00$ & $1.188 .000,00$ & $14.880 .000,00$ \\
\hline BRASIL TELECOM S/A & & $90.000,00$ & $150.000,00$ & $240.000,00$ & & $90.000,00$ & $150.000,00$ & $480.000,00$ \\
\hline BRASKEM S.A. & $17.515 .441,12$ & $324.380,00$ & $1.608 .000,00$ & $19.447 .821,12$ & $24.462 .364,24$ & $417.060,00$ & $1.663 .200,00$ & $79.627 .872,72$ \\
\hline BRF - BRASIL FOODS SA & $16.769 .132,10$ & $325.381,00$ & $2.645 .590,13$ & $19.740 .103,23$ & $13.760 .385,35$ & $350.763,71$ & $3.261 .597,23$ & $52.118 .238,87$ \\
\hline BROOKFIELD INCORPORAÇÕES S.A. & $17.561 .396,00$ & & $653.697,00$ & $18.215 .093,00$ & $27.648 .495,00$ & & $800.000,00$ & $56.896 .990,00$ \\
\hline CESP - CIA ENERGETICA DE SAO PAULO & $1.476 .638,59$ & $192.400,00$ & $1.243 .200,00$ & $2.912 .238,59$ & $1.476 .638,59$ & $192.400,00$ & $1.243 .200,00$ & $8.736 .715,77$ \\
\hline CIA BRASILEIRA DE MEIOS DE PAGAMENTO & $6.437 .612,82$ & $280.730,78$ & $627.500,00$ & $7.345 .843,60$ & $17.500 .000,00$ & $485.000,00$ & $1.500 .000,00$ & $58.455 .000,00$ \\
\hline
\end{tabular}




\begin{tabular}{|c|c|c|c|c|c|c|c|c|}
\hline \multirow[b]{2}{*}{ Razão Social da Companhia Aberta } & \multicolumn{3}{|c|}{2009} & \multirow{2}{*}{$\begin{array}{c}\text { Total para } \\
2009\end{array}$} & \multicolumn{3}{|c|}{2010} & \multirow{2}{*}{$\begin{array}{c}\text { Total para } \\
2010\end{array}$} \\
\hline & $\begin{array}{l}\text { Conselho de } \\
\text { Administração }\end{array}$ & $\begin{array}{c}\text { Conselho } \\
\text { Fiscal }\end{array}$ & Diretoria & & $\begin{array}{c}\text { Conselho de } \\
\text { Administração }\end{array}$ & $\begin{array}{c}\text { Conselho } \\
\text { Fiscal }\end{array}$ & Diretoria & \\
\hline CIA ENERG MINAS GERAIS - CEMIG & $3.549 .507,59$ & $154.237,34$ & $990.648,00$ & 4.694.392,93 & & & & \\
\hline $\begin{array}{l}\text { CIA SANEAMENTO BÁSICO ESTADO SÃO } \\
\text { PAULO }\end{array}$ & $1.842 .376,08$ & $192.420,00$ & $961.482,00$ & $2.996 .278,08$ & $1.842 .376,08$ & $192.420,00$ & $961.482,00$ & $8.988 .834,24$ \\
\hline CIA SIDERURGICA NACIONAL & $20.537 .085,00$ & & $1.464 .000,00$ & $22.001 .085,00$ & $58.246 .734,00$ & & $1.752 .000,00$ & $119.997 .468,00$ \\
\hline COMPANHIA BRASILEIRA DE DISTRIBUIÇÃO & $48.484 .058,00$ & $360.000,00$ & $7.485 .543,00$ & $56.329 .601,00$ & $53.065 .259,00$ & $432.000,00$ & $7.638 .000,00$ & $183.405 .777,00$ \\
\hline $\begin{array}{l}\text { COMPANHIA DE BEBIDAS DAS AMÉRICAS- } \\
\text { AMBEV }\end{array}$ & $56.825 .029,00$ & $1.062 .896,00$ & $10.535 .577,00$ & $68.423 .502,00$ & $56.135 .217,00$ & $1.169 .186,00$ & $9.638 .964,00$ & $200.830 .101,00$ \\
\hline $\begin{array}{l}\text { COMPANHIA DE CONCESSÕES } \\
\text { RODOVIÁRIAS }\end{array}$ & $21.102 .000,00$ & $132.000,00$ & $1.002 .000,00$ & $22.236 .000,00$ & $21.019 .000,00$ & $137.000,00$ & $1.042 .000,00$ & $66.594 .000,00$ \\
\hline COMPANHIA PARANAENSE DE ENERGIA & $5.643 .743,35$ & $644.864,32$ & $895.665,44$ & $7.184 .273,11$ & $6.021 .089,01$ & $639.901,34$ & $896.221,35$ & $22.671 .635,10$ \\
\hline $\begin{array}{l}\text { COMPANHIA PAULISTA DE FORCA LUZ - } \\
\text { CPFL }\end{array}$ & $4.467 .000,00$ & $60.000,00$ & $29.000,00$ & $4.556 .000,00$ & $4.453 .000,00$ & & $30.000,00$ & $8.966 .000,00$ \\
\hline COSAN SA INDUSTRIA E COMERCIO & $9.825 .433,88$ & $157.405,59$ & $781.772,56$ & $10.764 .612,03$ & $8.827 .108,65$ & $183.445,56$ & $746.394,72$ & $29.270 .846,79$ \\
\hline CYRELA BRAZIL REALTY SA EMPRS E PARTS & $8.729 .000,00$ & & $531.206,00$ & $9.260 .206,00$ & $9.080 .425,00$ & & $919.575,00$ & $20.000 .000,00$ \\
\hline DURATEX S.A. & $16.286 .815,50$ & $54.000,00$ & $2.099 .584,40$ & $18.440 .399,90$ & $33.300 .000,00$ & & $2.700 .000,00$ & $72.000 .000,00$ \\
\hline $\begin{array}{l}\text { ELETROBRÁS PARTICIPAÇÕES S.A. - } \\
\text { ELETROPAR }\end{array}$ & $779.541,95$ & $80.395,23$ & $107.193,68$ & $967.130,86$ & & & & \\
\hline $\begin{array}{l}\text { ELETROPAULO METROPOLITANA } \\
\text { EL.S.PAULO S.A }\end{array}$ & $7.341 .202,00$ & $505.200,00$ & $345.600,00$ & $8.192 .002,00$ & $10.667 .758,00$ & $576.000,00$ & $1.386 .720,00$ & $37.891 .434,00$ \\
\hline FIBRIA CELULOSE S.A. & $24.146 .596,95$ & $334.209,00$ & $622.351,44$ & $25.103 .157,39$ & 19.182.004,98 & $316.113,24$ & $1.638 .941,08$ & $63.411 .177,90$ \\
\hline GAFISA SA & $15.468 .895,00$ & & $975.000,00$ & $16.443 .895,00$ & $8.433 .481,00$ & $136.800,00$ & $1.211 .400,00$ & $29.345 .043,00$ \\
\hline GERDAU SA & $1.535 .952,00$ & $336.000,00$ & $6.967 .868,00$ & $8.839 .820,00$ & $2.000 .584,00$ & $369.600,00$ & $11.650 .858,00$ & $42.063 .126,00$ \\
\hline
\end{tabular}




\begin{tabular}{|c|c|c|c|c|c|c|c|c|}
\hline \multirow[b]{2}{*}{ Razão Social da Companhia Aberta } & \multicolumn{3}{|c|}{2009} & \multirow{2}{*}{$\begin{array}{l}\text { Total para } \\
2009\end{array}$} & \multicolumn{3}{|c|}{2010} & \multirow{2}{*}{$\begin{array}{l}\text { Total para } \\
2010\end{array}$} \\
\hline & $\begin{array}{l}\text { Conselho de } \\
\text { Administração }\end{array}$ & $\begin{array}{l}\text { Conselho } \\
\text { Fiscal }\end{array}$ & Diretoria & & $\begin{array}{l}\text { Conselho de } \\
\text { Administração }\end{array}$ & $\begin{array}{c}\text { Conselho } \\
\text { Fiscal }\end{array}$ & Diretoria & \\
\hline GOL LINHAS AEREAS INTELIGENTES SA & $19.799 .179,04$ & & $960.000,00$ & $20.759 .179,04$ & $28.015 .871,54$ & & $1.200 .000,00$ & $58.431 .743,08$ \\
\hline ITAÚ UNIBANCO HOLDING S.A. & $126.776 .194,00$ & $587.000,00$ & $7.341 .461,00$ & $134.704 .655,00$ & $87.650 .000,00$ & $663.000,00$ & $8.250 .000,00$ & $289.689 .000,00$ \\
\hline ITAÚSA - INVESTIMENTOS ITAÚ S.A. & 7.161.172,00 & $635.000,00$ & $11.085 .015,00$ & $18.881 .187,00$ & $6.640 .000,00$ & $663.000,00$ & $8.360 .000,00$ & $46.989 .000,00$ \\
\hline JBS SA & $3.359 .545,60$ & $292.010,40$ & $2.040 .000,00$ & $5.691 .556,00$ & & & & \\
\hline KLABIN S.A. & $4.995 .732,47$ & $1.474 .148,53$ & $11.306 .471,95$ & $17.776 .352,95$ & $10.824 .528,30$ & $1.553 .031,11$ & $11.324 .506,20$ & $71.106 .196,83$ \\
\hline LIGHT SA & $1.112 .965,00$ & $369.120,00$ & $234.000,00$ & $1.716 .085,00$ & $1.314 .409,00$ & $442.944,00$ & $499.690,00$ & $6.771 .129,00$ \\
\hline LLX LOGISTICA SA & $5.169 .341,11$ & $144.000,00$ & $4.396 .205,83$ & $9.709 .546,94$ & $5.500 .171,24$ & $180.000,00$ & $585.000,00$ & $18.795 .513,72$ \\
\hline LOJAS AMERICANAS SA & $12.362 .494,00$ & $307.389,00$ & $651.445,00$ & $13.321 .328,00$ & $25.328 .640,00$ & $433.043,00$ & $1.101 .306,00$ & $80.588 .967,00$ \\
\hline LOJAS RENNER SA & 23.145.916,09 & $203.437,44$ & $1.045 .000,00$ & $24.394 .353,53$ & $19.472 .720,88$ & $208.970,28$ & $1.023 .700,00$ & $62.116 .173,48$ \\
\hline MARFRIG ALIMENTOS SA & $5.219 .946,00$ & & $2.194 .494,00$ & $7.414 .440,00$ & & & & \\
\hline METALURGICA GERDAU SA & $94.792,00$ & $280.000,00$ & $3.499 .567,00$ & $3.874 .359,00$ & $66.667,00$ & $330.000,00$ & $2.458 .667,00$ & $8.566 .002,00$ \\
\hline MMX MINERAÇÃO E METÁLICOS S.A. & $6.057 .938,94$ & & $5.398 .208,00$ & $11.456 .146,94$ & $2.995 .000,00$ & & $765.000,00$ & $7.520 .000,00$ \\
\hline MRV ENGENHARIA E PARTICIPAÇÕES S/A & $5.989 .000,00$ & & $555.000,00$ & $6.544 .000,00$ & & & & \\
\hline NATURA COSMETICOS SA & $7.988 .700,00$ & & $5.497 .900,00$ & $13.486 .600,00$ & $10.130 .100,00$ & & $5.250 .100,00$ & $30.760 .400,00$ \\
\hline OGX PETRÓLEO E GÁS PARTICIPAÇÕES S/A & $69.080 .288,00$ & & $16.586 .562,00$ & $85.666 .850,00$ & $51.242 .279,00$ & & $12.783 .061,00$ & $128.050 .680,00$ \\
\hline $\begin{array}{l}\text { PDG REALTY SA EMPREENDIMENTOS E } \\
\text { PARTS }\end{array}$ & $17.949 .198,25$ & $36.000,00$ & $791.633,50$ & $18.776 .831,75$ & $56.387 .766,14$ & $120.000,00$ & $1.100 .000,00$ & $172.823 .298,42$ \\
\hline
\end{tabular}




\begin{tabular}{|c|c|c|c|c|c|c|c|c|}
\hline \multirow[b]{2}{*}{ Razão Social da Companhia Aberta } & \multicolumn{3}{|c|}{2009} & \multirow{2}{*}{$\begin{array}{c}\text { Total para } \\
2009\end{array}$} & \multicolumn{3}{|c|}{2010} & \multirow{2}{*}{$\begin{array}{c}\text { Total para } \\
2010\end{array}$} \\
\hline & $\begin{array}{l}\text { Conselho de } \\
\text { Administração }\end{array}$ & $\begin{array}{c}\text { Conselho } \\
\text { Fiscal }\end{array}$ & Diretoria & & $\begin{array}{l}\text { Conselho de } \\
\text { Administração }\end{array}$ & $\begin{array}{c}\text { Conselho } \\
\text { Fiscal }\end{array}$ & Diretoria & \\
\hline PETRÓLEO BRASILEIRO S.A. - PETROBRAS & $6.509 .074,41$ & $372.117,85$ & $590.197,40$ & $7.471 .389,66$ & $9.727 .505,44$ & $419.376,85$ & $693.136,68$ & $32.520 .056,91$ \\
\hline REDECARD S/A & $11.095 .599,27$ & & $1.752 .000,00$ & $12.847 .599,27$ & $16.733 .981,80$ & & $2.175 .000,00$ & $18.908 .981,80$ \\
\hline ROSSI RESIDENCIAL SA & $6.691 .599,78$ & $76.050,00$ & $1.240 .834,23$ & $8.008 .484,01$ & 7.643.173,92 & $202.800,00$ & $1.484 .573,89$ & $27.991 .643,43$ \\
\hline SOUZA CRUZ SA & $15.159 .110,00$ & $198.000,00$ & $752.000,00$ & $16.109 .110,00$ & & & & \\
\hline TAM S.A. & $9.256 .191,50$ & & $1.159 .295,00$ & $10.415 .486,50$ & & & & \\
\hline TELE NORTE LESTE PARTICIPAÇÕES SA & - & $299.040,00$ & $2.000 .000,04$ & $2.299 .040,04$ & - & $536.825,03$ & $3.590 .322,61$ & $12.381 .442,92$ \\
\hline $\begin{array}{l}\text { TELECOMUNICAÇÕES DE SÃO PAULO S/A } \\
\text { TELESP }\end{array}$ & $17.269 .551,72$ & $598.804,94$ & $3.664 .126,00$ & $21.532 .482,66$ & $17.972 .484,21$ & $607.121,32$ & $3.706 .394,47$ & $66.858 .000,00$ \\
\hline TELEMAR NORTE LESTE SA & $4.567 .044,35$ & $90.720,00$ & $2.804 .549,89$ & $7.462 .314,24$ & $5.478 .779,74$ & $177.921,26$ & $3.540 .156,87$ & $27.590 .573,61$ \\
\hline TIM PARTICIPAÇÕES SA & $3.020 .751,26$ & $690.000,00$ & $468.000,00$ & $4.178 .751,26$ & $3.650 .000,00$ & $750.000,00$ & $672.000,00$ & $15.216 .000,00$ \\
\hline ULTRAPAR PARTICIPAÇÕES SA & $16.041 .160,66$ & $480.000,00$ & $2.188 .000,00$ & $18.709 .160,66$ & $19.575 .056,07$ & $574.800,00$ & $2.351 .040,00$ & $67.502 .688,21$ \\
\hline $\begin{array}{l}\text { USINAS SIDERURGICAS DE MINAS GERAIS } \\
\text { SA }\end{array}$ & $11.872 .642,50$ & $372.404,04$ & $1.709 .861,26$ & $13.954 .907,80$ & $16.490 .000,00$ & $506.000,00$ & $1.402 .476,00$ & $55.195 .428,00$ \\
\hline VALE S.A. & $43.047 .646,79$ & $824.000,00$ & $3.249 .794,00$ & $47.121 .440,79$ & $73.827 .033,00$ & $1.152 .000,00$ & $4.554 .000,00$ & $238.599 .099,00$ \\
\hline VIVO PARTICIPAÇÕES SA & $441.211,00$ & $180.000,00$ & $1.266 .454,00$ & $1.887 .665,00$ & $624.007,00$ & $180.000,00$ & $1.728 .000,00$ & $7.596 .021,00$ \\
\hline
\end{tabular}




\section{Bibliografia}

BEBCHUK, Lucian A.; FRIED, Jesse M., "Paying for long-term performance", University of Pennsylvania Law Review, Vol. 158, p. 1915-1959, 2010 [The Social Science Research Network Electronic Paper Collection: http://ssrn.com/abstract=1535355]

BEDICKS, Heloisa Belotti, Governança corporativa e dispersão de capital: múltiplos casos no Brasil, São Paulo, Saint Paul Editora, 2009

BORBA, José Edwaldo Tavares. Direito Societário, 12ª edição, Rio de Janeiro, Renovar, 2010.

CARVAlHOSA, Modesto. Comentários à lei de Sociedades Anônimas: Lei $n^{o}$. 6.404, de 15 de dezembro de 1976. vol. 3, artigos 138 a 205. São Paulo. Saraiva, 1998. p. 222.

CHILOSI, Alberto; DAMIANI, Mirella, "Stakeholders vs. Shareholders in Corporate Governance", relatório de pesquisa da Universidade de Pisa, texto eletrônico disponível em [http://ssrn.com/abstract=975293].

COMISSÃO DE VALORES MOBILIÁRIOS, Cartilha "Recomendações da CVM sobre Governança Corporativa”, in 〈http://www.cvm.gov.br>, 2002.

HILL, Jennifer G., "New Trends in the Regulation of Executive Remuneration", DIRECTORS IN TROUBLED TIMES, pp. 100-123, R. P. Austin and A. Y. Bilski, eds., Ross Parsons Centre of Commercial, Corporate and Taxation Law, 2009

IBGC, Instituto Brasileiro de Governança Corporativa. Código das Melhores Práticas de Governança Corporativa, 4ª edição, IBGC, São Paulo, 2009. 
JENSEN, Michael C.; MURPHY, Kevin J., “CEO Incentives-It's not how much you pay, but how", Harvard Business Review, May-June 1990, No. 3, pp $138-153$

LA PORTA, Rafael, SHLEIFER, A., LOPEZ-DE-SILANES, F., VISHNY, R. Law and Finance, Journal of Political Economy v. 106, p. 1113-1155, 1998.

LAZZARESCHI NETO, Alfredo Sérgio, Lei das Sociedades por ações anotada, $3^{\text {a }}$ ed. rev. atual. e ampl., São Paulo, Saraiva, 2010.

SAlOMÃO FILHO, Calixto. O Novo Direito Societário, $2^{\mathrm{a}}$ ed., São Paulo: Malheiros, 2002.

SILVEIRA, Alexandre di Miceli da. Governança Corporativa no Brasil e no Mundo, Rio de Janeiro, Elsevier, 2010.

MARQUES, Fabíola; ABUD, Cláudia José Direito do Trabalho, $5^{\mathrm{a}}$ ed., São Paulo: Atlas, 2009.

MARTINS, Sergio Pinto. Direito do Trabalho, $17^{\mathrm{a}}$ ed., São Paulo: Atlas, 2003.

MORCK R.; SHLEIFER A.; VISHNY RW, "Management ownership and market valuation: an empirical analysis". Journal of Finance Economics 20(1-2): p. 293-315, 1988.

REBELLI, Felipe, Towers Watson, apresentação "Práticas e tendências em remuneração de administradores e executivos", Expomoney, São Paulo , em 26 de março de 2010 [http://www.towerswatson.com/].

REQUIÃO, Rubens, Curso de direito comercial, $2^{\circ}$ volume, $27^{\mathrm{a}}$ ed. Ver. E atual. Por Rubens Edmundo Requião, São Paulo, Saraiva, 2010. 